\title{
ENVIRONMENTAL REGULATION AND INDUSTRY EMPLOYMENT: A REASSESSMENT
}

by

\author{
Anna Belova \\ Abt Associates Inc
}

\author{
Wayne B. Gray \\ Clark University
}

\author{
Joshua Linn \\ Resources for the Future
}

Richard D. Morgenstern
Resources for the Future

CES 13-36 July, 2013

The research program of the Center for Economic Studies (CES) produces a wide range of economic analyses to improve the statistical programs of the U.S. Census Bureau. Many of these analyses take the form of CES research papers. The papers have not undergone the review accorded Census Bureau publications and no endorsement should be inferred. Any opinions and conclusions expressed herein are those of the author(s) and do not necessarily represent the views of the U.S. Census Bureau. All results have been reviewed to ensure that no confidential information is disclosed. Republication in whole or part must be cleared with the authors.

To obtain information about the series, see www.census.gov/ces or contact Fariha Kamal, Editor, Discussion Papers, U.S. Census Bureau, Center for Economic Studies 2K132B, 4600 Silver Hill Road, Washington, DC 20233, CES.Papers.List@census.gov. 


\begin{abstract}
This paper examines the impact of environmental regulation on industry employment, using a structural model based on data from the Census Bureau's Pollution Abatement Costs and Expenditures Survey. This model was developed in an earlier paper (Morgenstern, Pizer, and Shih (2002) - MPS). We extend MPS by examining additional industries and additional years. We find widely varying estimates across industries, including many implausibly large positive employment effects. We explore several possible explanations for these results, without reaching a satisfactory conclusion. Our results call into question the frequent use of the average impacts estimated by MPS as a basis for calculating the quantitative impacts of new environmental regulations on employment.
\end{abstract}

\footnotetext{
* This paper was prepared in fulfillment of EP-W-11-003 WA 1-23 (Task 4) and WA 2-23 (Task 4). Although the research described in this paper has been funded by the U.S. Environmental Protection Agency (EPA), it has not been subject to the Agency's review and therefore does not necessarily reflect the views of the Agency, and no official endorsement should be inferred.

We thank Randy Becker, Ann Ferris, Michael Greenstone, John Haltiwanger, Robin Jenkins, Alex Marten, Al McGartland, Billy Pizer, Ron Shadbegian, Glenn Sheriff, Jhih-Shyang Shih, Kerry Smith, Brett Snyder, Reed Walker, and participants of the EPA-Sponsored Conference "Advancing the Theory and Methods for Understanding Employment Effects of Environmental Regulation" for their comments on earlier versions of the paper. We also thank Jim Davis at the Boston Research Data Center for his continued help; Wang Jin and Shital Sharma for excellent research assistance; and Diane Ferguson for editorial assistance.
} 


\section{INTRODUCTION}

The "jobs vs. environment" debate has been raging in the United States and elsewhere since the 1970s, although interest has clearly intensified during the recent economic downturn. At the same time, conclusive evidence on the employment impacts of such regulation is quite limited, largely because the effects of environmental regulation on labor markets are so difficult to disentangle from other economic changes over time and across industries.

The policy debate has spawned alternative definitions of regulation-induced job loss. While an individual separated from an existing job because of an environmental regulation has clearly suffered a loss, pollution abatement activities themselves require labor input. Thus, environmental regulations may also create jobs - sometimes in the same industry, the same firm, or even the same plant. Although headlines rarely make the linkage, job loss in one area may be accompanied by job creation in another (e.g., when environmental regulation causes firms to shift production from counties not attaining one or more federal air quality standards to those in compliance). Henderson (1996), Becker and Henderson (2000), and Greenstone (2002) have found such job shifts using linear regression models based on these spatial, pollutant-specific differences in regulation. However, the number of jobs moving from non-attainment to attainment areas may overstate the effects on industry or economy-wide employment.

Labor unions and trade groups often focus on gross job changes and the cost of rearranging workers within an industry. However, net job loss within an industry - which recognizes all intraindustry employment changes associated with environmental regulation - is also an important metric. This definition recognizes that many regulated firms relocate employees in other units of the same company, and that plants remaining in the industry often expand output to make up for the reduced production due to exiting or shrinking plants in the same industry, thereby offsetting at least some of the initial job losses.

Morgenstern, Pizer, and Shih (2002) (hereinafter MPS) measured regulatory burden or stringency via a widely used proxy, pollution abatement operating costs (PAOC), reported in the Pollution Abatement Costs and Expenditures (PACE) Survey. ${ }^{1}$ MPS developed a structural model to link PAOC and employment, and decomposed the employment consequences of PAOC into a cost effect, a factor shift, and a demand effect. ${ }^{2}$ Standard theory predicts a positive cost effect and a negative demand effect, while the sign of the factor shift could go either way, making the direction of the net impacts indeterminate ex ante.

Using plant-level Census data from 1979-91 for four pollution-intensive industries, MPS estimated a cost function that allowed assessment of the first two components and then combined the results with estimates of industry-wide demand elasticities to calculate the third component. They

\footnotetext{
${ }^{1}$ As Gallaher, Morgan and Shadbegian (2008) noted, the PACE is "the only comprehensive source of pollution abatement costs and expenditures related to environmental protection in the manufacturing sector of the United States" ( $p$ 309). They also cited the now considerable literature examining the reasons why the PACE survey may either under- or overstate the true costs of pollution abatement. See also Becker and Shadbegian (2007).

${ }^{2}$ For a somewhat similar approach, see Berman and Bui (2001).
} 
combined the components to estimate the net change in employment associated with changes in reported PAOC. Aggregating over four industries, they found a small, statistically insignificant, gain of jobs associated with PAOC. The positive value was driven by the results from the plastics and petroleum industries, which had significantly positive factor shifts coupled with relatively small demand effects.

Because of the importance of MPS in this debate, we used a similar methodology and addressed two key questions: (1) does the effect of environmental regulation vary across industries; and (2) has the nature or magnitude of the effect changed over time? Like MPS, we did not find any evidence of large negative effects. However, for some industries and time periods, we obtained very large positive effects. The magnitudes of these effects seem to imply that nearly all of the regulatory expenditure is used to hire workers. This is implausible because of the capital intensity of pollution abatement in these industries.

After reporting the main results, we describe extensive additional analysis trying to explain these results. One possibility is that the MPS methodology was sensitive to the sample, but in some cases we also obtained implausible results using a linear regression model rather than the model in MPS. Alternatively, there may have been an omitted variables problem that was apparent in our samples but less severe in the MPS samples. We were not able to identify suitable instruments or alternative strategies to address this possibility.

A key limitation of the MPS approach was the exclusive focus on continuing plants. Relying on a balanced panel, the approach excluded those facilities that exited the industry during the study period, thereby precluding analysis of the potential impact of regulation on exit. During our project we began to examine this issue by developing a preliminary analysis of the exit decision by plants in these industries. Perhaps unsurprisingly, we found a quite limited impact of regulation on exit probabilities, with mostly small and insignificant effects, including decreases as well as increases in exit associated with higher PAOC across the industries. ${ }^{3}$

The paper is organized as follows. The next section briefly lays out the framework for decomposing industry-level employment effects. Section 3 describes the methodology and data for estimating employment effects. Section 4 presents the results for these plants. Section 5 discusses possible explanations for the implausible results. Section 6 provides conclusions.

\section{FRAMEWORK FOR DECOMPOSING INDUSTRY-LEVEL EMPLOYMENT EFFECTS}

This section first provides an overview of the MPS approach and then discusses the extensions developed herein.

\subsection{Overview of MPS Methodology}

Recognizing that when environmental regulations change, both a rearrangement of production activities and a potential output contraction affect employment, MPS developed a structural model to estimate the relationship between regulatory costs and output. An advantage of the structural approach was that it enabled a decomposition of the employment effects into the cost, factor shift,

\footnotetext{
${ }^{3}$ Exit analysis results are available at

http://yosemite.epa.gov/ee/epa/eerm.nsf/vwAN/EE-0572-07.pdf/\$file/EE-0572-07.pdf
} 
and demand components (further described below). As MPS emphasized, the public debate has focused mostly on the demand effect. However, this focus ignores the fact that employment could rise if demand is less than unit elastic or if production becomes more labor intensive. Thus, disentangling the three effects can help clarify the relationship between regulation and employment.

MPS defined their disaggregation as follows:

a) Cost effect: As production costs increase from added pollution abatement activities, plants use more of all inputs (including labor) to produce the same level of output.

b) Factor shift: Post-regulation production technologies may be more or less labor intensive (i.e., more or less labor may be required per dollar of output).

c) Demand effect: Higher production costs raise market prices. Higher prices reduce consumption (and production), thereby reducing demand for labor within the regulated industry.

The cost effect depends on the relationship between regulatory costs and total costs. The stronger the relationship is, the greater the effect. Theoretically, the cost effect is positive, meaning that an increase in regulatory stringency causes employment to increase via the cost effect. In contrast, the factor shift depends on whether regulatory costs induce substitution toward or away from labor while holding total costs constant. In principle, the factor shift could be either positive or negative.

MPS estimated these two effects by estimating a plant-level cost function that included regulatory costs as well as the costs of four productive inputs: capital, labor, energy, and materials. MPS showed that the cost effect and factor shift depend on the cost function parameters and input cost shares. We used the same functional form to estimate plant-level cost functions.

Assuming monopolistic competition among plants in an industry, MPS showed that the demand effect depends on the elasticity of total industry output demand with respect to the output price. The more elastic industry output demand is, the more an increase in costs reduces total industry output and thus employment. MPS estimated the demand elasticity using aggregate industry-level data. As the next section discusses, we made the same monopolistic competition assumption, but the estimation of demand elasticities differed in several important ways.

After estimating cost function parameters and demand elasticities, MPS estimated the employment effects of a hypothetical increase in regulatory costs. MPS made the not unreasonable assumption that the plant's share of regulatory costs was proportional to its share of total industry output - an assumption that we continued to employ.

\subsection{Expanding the Time Period and Set of Industries Analyzed}

We next discuss the extensions to MPS. MPS used plant observations from 1979-1981, 1985, 1989 , and 1991. The MPS analytical datasets were assembled from several surveys, but two of them were not conducted continuously: the PACE survey, which collects information on expenditures related to environmental regulation, and the Manufacturing Energy Consumption Survey (MECS), which collects information on energy costs. MPS did not include all years in the 1979-1991 time period because they restricted the analysis to years in which both the PACE and MECS were conducted. 
However, by performing some simple extrapolations (see Section 3 for more details), we were able to extend the analysis to all years from 1976 to 1991, with the exception of the two years the PACE survey was unavailable due to quality concerns (1983) or was not conducted (1987). Beyond the addition of years from the 1970s and 1980s, we extended the analysis forward to include the years 1992-1994, 1999 , and 2005. This extension allowed us to examine whether the employment effects of PAOC have changed over time.

MPS chose their original four industries because their reported regulatory costs per value of output were among the highest in the manufacturing sector. However, plants in other industries also face stringent environmental regulation. Because of differences in production structure, industry organization, and location, the employment effects of environmental regulation are likely to vary across industries. Consequently, we generated the estimates for six additional industries as described in Section 3. These industries are also heavily regulated; have some of the highest ratios of reported regulatory costs to value of output; and, at least in some cases, are likely to be the focus of additional EPA regulations in the future.

\section{METHODOLOGY AND DATA FOR ESTIMATING EMPLOYMENT EFFECTS}

This section describes the details of the methodology for estimating employment. Our methodology made use of the same assumptions as MPS and introduced the extensions noted above. The section first defines the industries analyzed and then describes the demand elasticity and cost function estimation and data.

\subsection{Industry Selection}

To update MPS, we started with the original four industries: petroleum, plastics, pulp and paper, and iron and steel. The industry definitions for plastics and petroleum remained the same, while we dropped coke ovens from the steel industry (consistent with the industry definition in the North American Industry Classification System (NAICS)) and included pulp-only mills in the paper industry (because they face regulatory pressures similar to paper mills that produce their own pulp). We chose additional industries for analysis based on potential sample sizes of Census data and on informal consultation with technical experts to assess the likely degree of homogeneity of production functions within the selected industries.

The final set of 10 industries included the 4 from MPS plus 6 others. Table 1 lists these industries and their corresponding industry codes. One issue in dealing with these data was the switch of industry definitions from Standard Industrial Classification (SIC) to NAICS codes in 1997. This was less of a problem when dealing with the individual plant-level data, since we could identify the same plant over time even when it changed industries. However, some of our variables were based on industrylevel information, so care was needed if industry definitions changed dramatically in 1997. As it turns out, of the four MPS industries, two (petroleum and plastics) were exact one-to-one matches between SIC and NAICS, one (steel) was near-exact (93-96 percent of SIC shipments were from a single NAICS industry), and the other (pulp and paper) had a somewhat weaker match (in the 82-88 percent range), largely because of the shifting in/out of paperboard/box plants. 


\subsection{Analysis}

\subsubsection{Estimation of Industry Demand Elasticities}

The own-price elasticity of industry demand, reflecting the change in total industry output given a change in the average price of output, was an important parameter in the MPS model used to simulate the effect of PAOC on industry-level employment. The larger the elasticity (in absolute value), the more industry output falls when PAOC increases, and the larger the demand effect. Our estimation strategy used the same industry definitions as the cost function analysis. We estimated a simple demand equation and instrument for output price. ${ }^{4}$

\subsubsection{Empirical Strategy}

The industry demand elasticity is distinct from a plant's demand elasticity. The latter is much more commonly estimated in the literature. It is typically estimated using variation in output prices and output across plants, and the elasticity therefore reflects the change in demand for a plant's output given a change in its price relative to the prices of all other plants in the industry. For example, Foster, Haltiwanger, and Syverson (2008, henceforth FHS) estimated plant-level elasticities using the Census plant-level microdata from the Longitudinal Research Database (LRD). The industry demand elasticity should be smaller in magnitude (less elastic) than the plant-level demand elasticity because it corresponds to the reduction in total industry output if all plant input prices increase by the same amount.

We estimated the industry demand elasticity using industry-level variables. We began with the following equation for each industry:

$$
\ln q_{j t}=\beta_{0 j}+\beta_{1 j} \ln p_{j t}+\varepsilon_{j t}
$$

where $q_{j t}$ is the output of industry $j$ in year $t, p_{j t}$ is the price of the output, $\varepsilon_{j t}$ is an error term, and $\beta_{0 j}$ and $\beta_{1 j}$ are industry-specific coefficients to be estimated. The coefficient $\beta_{1 j}$ is the elasticity of output with respect to the price of output, and represents the percentage change in quantity demanded given a 1 percent price increase. That is, the elasticity captures movement along the aggregate industry demand curve caused by a price change.

Estimating equation (1) by ordinary least squares (OLS) using equilibrium prices and quantities is likely to yield an estimate of $\beta_{1 j}$ that is upward biased. The reason is the same as for a plant-level analysis: at least some of the variation in equilibrium prices is driven by shifting demand curves. For example, consider the petroleum refining industry. If a recession causes a decrease in demand for petroleum products, refineries are likely to cut their prices. Because the error term includes all determinants of equilibrium quantity besides the price, the error term is therefore positively correlated with the price, and the coefficient on the log output price is upward biased.

${ }^{4}$ By comparison, MPS used the Jorgenson KLEM dataset, which contains similar, although not identical industry definitions for the four MPS industries. (The details on the Jorgenson KLEM dataset are available in Appendix B.) Furthermore, MPS do not explicitly estimate a demand equation; instead, the main independent variable is the difference between the output price and an aggregate input price index. 
One approach to reducing this bias is to control for demand shocks. When estimating plantlevel demand elasticities, it is common to include year fixed effects or measures of total industry output, for example, as in FHS. However, we defined equation (1) at the industry level, and it would not have been possible to estimate industry-specific demand elasticities if we included year fixed effects. $^{5}$

Instead, we constructed a measure of aggregate industry demand:

$$
\bar{Q}_{j t}=\sum_{k \neq j} \bar{s}_{k j} q_{k t}
$$

where $\bar{s}_{k j}$ is the share of output from industry $j$ in industry $k^{\prime}$ s total materials use and $q_{k t}$ is the output of industry $k$ in year $t$. The summation is taken over all industries other than industry $j$ as well as final consumers, so that $\bar{Q}_{j t}$ is an estimate of the demand for industry $j^{\prime}$ 's output from all other industries and consumers. ${ }^{6}$

We added aggregate demand to equation (1) to obtain:

$$
\ln q_{j t}=\beta_{0 j}+\beta_{1 j} \ln p_{j t}+\beta_{2 j} \ln \bar{Q}_{j t}+\varepsilon_{j t}
$$

Importantly, we constructed the aggregate demand measure using cost shares computed in a base year and changes in industry-level output over time. Using time-invariant shares alleviated concerns that the shares could be correlated with the error term. At the same time, because cost shares were fixed, $\bar{Q}_{j t}$ proxies for aggregate demand and measurement error for aggregate demand could bias other coefficients.

Given this concern, we also used an instrument for the output price. Appropriate instruments are correlated with the price but are uncorrelated with demand for industry output. Supply-side variables (i.e., cost-shifters) are commonly used in the literature on demand curve estimation. FHS estimated plant-level demand elasticities and used the plant's total factor productivity (TFP) as an instrument.

We could use the industry-level analog of plant-level TFP:

$$
\ln T F P_{j t}=\ln q_{j t}-\sum_{z=k_{i} l_{i}, m} \alpha_{j z} \ln x_{j z t}
$$

where inputs, indexed by $z$, include capital $(k)$, labor ( $l$ ), energy $(e)$, and materials $(m) ; \alpha_{j z}$ is the cost share of input $z$ computed over all years; and $x_{j z t}$ is the consumption of input $z$. Note that the cost shares needed to be multiplied by the returns to scale of the industry that was estimated as part of the cost function estimation.

\footnotetext{
${ }^{5}$ We could have pooled industries and include year fixed effects, which would have controlled for aggregate shocks that affect all industries proportionally. This would not have controlled for industry-specific demand shocks, however, and would have likely yielded biased estimates using OLS.

${ }^{6}$ Input-output tables from the U.S. Department of Commerce's Bureau of Economic Analysis (BEA) indicate that manufacturing plants often consume output from other plants in the same industry. If we included output from industry $j$ when computing demand for industry $j$, however, there would have been a mechanical relationship between the dependent variable and aggregate demand.
} 
One concern with the instrument is that we computed it using the industry's output, which we also used to compute the dependent variable in equation (3). Measurement error in the input prices would therefore have biased the estimated coefficients.

Below we report results using a second set of instruments, which are the factor prices for industry $j$ in year $t$. These instruments are also potentially problematic in that macro shocks may be correlated with factor prices. Because of the limitations of both types of instruments (industry TFP and factor prices), we compare results using one or the other.

\subsubsection{Data}

We performed the demand elasticity estimation using publicly available industry-level data from the National Bureau of Economic Research and U.S. Census Bureau's Center for Economic Studies (NBER-CES) Manufacturing Productivity Database (MPD), BEA input-output tables, and BEA gross output by industry. ${ }^{7}$ The estimation sample included the years 1972-2005. For each six-digit NAICS industry, the MPD includes output; the output price; TFP; and prices of labor, energy, and materials. In cases where we estimated cost functions by aggregated six-digit NAICS industries, we aggregated the MPD variables by computing shipment-weighted averages.

We combined MPD and BEA data to construct aggregate demand. From the BEA input-output table, we computed the cost shares $\left(\bar{s}_{k j}\right)$ in a base year for each manufacturing industry, for each nonmanufacturing sector, and for end-use consumers. For each year from 1972 to 2005, we obtained output for each manufacturing industry from the MPD. We obtained output for non-manufacturing sectors and end-use consumers from the BEA gross output tables. We used a SIC-NAICS concordance to convert post-1997 output, which is on a NAICS basis, to a SIC basis. For each industry and sector, we computed annual growth rates as the difference in log output. We computed output in each year using the growth rates and the output in the base year. Finally, aggregate demand was the inner product of the cost shares and output.

\subsubsection{Estimation of Cost Functions}

\subsubsection{Empirical Strategy}

MPS built on the cost function-based model in Morgenstern, Pizer, and Shih (2001), which explored the relationship between PAOC and actual factor costs by explicitly distinguishing between environmental and non-environmental expenditures. Unlike some other papers that found reported PAOC understated true economic costs (e.g., Gray and Shadbegian, 1994; Joshi, Lave, Shih, and McMichael, 1997), Morgenstern, Pizer, and Shih (2001) found that, despite considerable variation at the industry level, the aggregate cost estimates did not appear to be under- or overstated on average, relative to reported PAOC. Importantly, their results hinged on the use of a fixed effects estimator that allowed for unspecified plant-level differences in productivity and factor intensities. This approach, they argued, corrected for an upward bias caused by plant-level omitted variables. See Appendix A for a description of the MPS cost function model.

${ }^{7}$ The NBER data are found at http://www.nber.org/data/nberces5809.html. BEA input-output data are available at http://www.bea.gov/industry/io benchmark.htm. 
An important consideration is whether sample selection affects the cost function estimates. For example, plants experiencing a negative shock to expected profitability are more likely to exit than other plants. Such exit could bias the cost function parameter estimates if unobserved and timevarying profitability shocks are correlated with other inputs; that is, the plant fixed effects control only for time-invariant shocks and not time-varying profitability shocks. Olley and Pakes (1996) used a model that allowed for time-varying profitability shocks and yielded unbiased estimates of production function parameters. Using the Olley-Pakes production function methodology to estimate the MPS cost function was outside the scope of this project, however. ${ }^{8}$ Instead, we estimated a production function that was the dual of the MPS cost function in two ways: OLS with plant fixed effects and the OlleyPakes model (available as a packaged Stata routine). Then, we compared the production function parameter estimates between the two estimations and assessed whether the estimated TFP from the Olley-Pakes model was stable over time, which would support the validity of using plant fixed effects to control for plant TFP when estimating the cost functions.

\subsubsection{Data}

Unfortunately, we did not have access to the original MPS data and code. ${ }^{9}$ Using our data, we attempted to follow the data generation process as described in MPS in order to estimate the comparable cost model. This included re-estimation of the model using the MPS years and industries, as well as extending the data sample to include additional years and industries. Appendix B contains a description of the data generation process and a table with summary statistics for MPS industries and years as well as for all industries and years. Appendix $C$ compares our process with the MPS process.

\subsection{Estimation of Aggregate Effects on Employment}

We used the empirical results to simulate the effect of a $\$ 1$ million increase in PAOC on total industry employment. These simulations were modeled after those in MPS, in which the PAOC increase was apportioned to each plant and year in the sample. MPS apportioned the increase in proportion to the share in total costs for the entire sample. As MPS showed, the aggregate industry effect depended on the measured cost shares and other variables as well as on the estimated parameters from the cost function and from equation (3); see Appendix A for further details.

\section{RESULTS}

This section presents results, comparing with MPS and comparing across years and industries. For many industries we found small aggregate employment effects, but in several cases we found positive and implausibly large effects. We discuss possible explanations for these findings in Section 5.

\subsection{Demand Elasticity Estimation}

Tables 2-4 report the estimates of equation (3). Each panel contains a different industry; Table 2 contains the four MPS industries, and the other tables show the remaining six industries. For

\footnotetext{
${ }^{8}$ Petrin and Warzynski (2012) developed a methodology that allows for plant-specific and time-varying unobserved shocks to a Cobb-Douglas cost function. Applying the approach to the MPS cost function, in which one of the outputs is not observed, is not straightforward.

${ }^{9}$ The original datasets and data management code used by MPS in the Census Research Data Center were not available to us because of the failure of the backup drive at the Census on which they had been archived.
} 
each industry, the estimation sample includes observations from the years 1972-2005. The dependent variable is the log of industry output, and Table 2 reports the coefficients on the log output price and log aggregate demand. Column 1 includes a linear time trend, and column 2 estimates equation (3) in first differences (omitting the time trend) to account for the strong persistence of the price and output variables.

In the first two columns in the tables, the estimates of the own-price elasticity are usually statistically significant at the 5 percent level and are almost always less than one in magnitude. The small magnitude implies that a 1 percent PAOC increase reduces industry output by less than 1 percent, so the demand effect is likely to be small. The small magnitude is also consistent with the interpretation of the coefficient as the own-price elasticity of industry output; plant-level elasticities (e.g., those reported in FHS) are typically much larger in magnitude. We observed that the coefficient on aggregate demand was positive and statistically significant in nearly all cases, as expected.

Estimating equation (3) by OLS, whether in levels or first differences, is likely to yield upwardbiased (less negative) estimates for the reasons discussed above. This bias suggests that we would have underestimated the magnitude of the demand effect if we had relied on OLS estimates of the industry demand elasticity. Consequently, columns 3 and 4 report estimates using industry TFP (column 3 ) and input prices (column 4) as instruments. The equation was estimated in first differences, and the results should be compared to column 2. We observed that the estimates using the TFP instrument tended to be larger in magnitude than the corresponding OLS estimates, but the standard errors were also quite large. This was the case because the first stage was fairly weak for many of the industries. By comparison, the first stage using input prices was much stronger, and the standard errors were much smaller in column 4. Consequently, these estimates constituted our preferred estimates. For all industries, the instrumental variables estimates were quite close to the OLS estimates.

\subsection{Cost Function Estimation}

We briefly discussed the parameter estimates before focusing on the estimated employment effects. Appendix D, Table D1, reports the parameter estimates for the cost function along with the original MPS estimates. The current and MPS estimates differed considerably. A key parameter in the employment effects estimates is $\alpha_{r}$, which is the degree of interaction between environmental and non-environmental activities. The more positive the estimate is, the larger the cost effect. Therefore, a more positive (or less negative) estimate implies a more positive (or less negative) total employment effect. A negative $\alpha_{r}$ implies a decrease in production costs whenever the PAOC-to-production cost ratio increases. Our estimates of $\alpha_{r}$ were much larger in magnitude (and of opposite sign in two cases), compared to those originally estimated by MPS. For the paper industry, the coefficient changed from -0.62 to 1.19 ; for the petroleum industry from 0.59 to 1.18 ; for the plastics industry from 0.38 to 4.78 ; and for the steel industry from -0.07 to 3.27 .

Appendix D, Table D2, reports the cost function estimates for all 10 industries using all available years of data. Estimates of $\alpha_{r}$ were greater than one for all MPS industries except paper (where $\alpha_{r}$ was negative and smaller than one in absolute value). Our estimate of $\alpha_{r}$ was negative for other electrical equipment, but for all other industries our estimate was positive. 


\subsection{Aggregate Employment Effects}

\subsubsection{MPS Industries and Years}

Table 5 presents the estimated employment effects for MPS industries and MPS years. Panel A, columns (4)-(7), shows the original MPS estimates. MPS reported the employment effects of a \$1 million PAOC increase measured in 1987 dollars. For consistency with the current estimates, we adjusted the MPS estimates to 1997 dollars using industry-level deflators. Panel B, columns (4)-(7), shows the estimates we obtained in our current analysis. Recall that our industry definitions for paper and steel are slightly different from those in MPS. However, we also estimated the model using the original MPS industry definitions, and the results were not materially different from the estimates reported here. The estimated cost effects and factor shifts in columns (5) and (6) do not depend on industry definition.

The total employment effect, in column (4), is positive in all four industries for the current estimates (Panel B). For plastics and steel, given average annual wages for production workers, the estimates suggested that most of the additional regulatory costs would be used for workers. This is implausible because of the capital intensity of pollution abatement expenditures in these industries.

Table 5 decomposes the total effects into the three components to further characterize the estimates. Looking first at the cost effects in column (5), it is evident that, except for the petroleum industry, the current estimates are substantially larger than the MPS estimates, particularly for plastics and steel. The differences between the current and MPS estimates for the factor shift and demand effects are smaller than those for the cost effect, except for the plastics industry, where we observed a large difference in the factor shift. Overall, the large cost effect explains much of the considerably larger total employment effect estimates reported in column (4).

For comparison with the structural estimates, we also reported estimated total employment effects using a reduced-form regression of log employment on PAOC and other variables included in the cost function estimation. The employment effects we estimated using the reduced-form equations, reported in column (3) of Panel B, are roughly similar to the estimates from the structural model, and are similarly implausibly large for the plastics and steel industries. This qualitative similarity between the structural and reduced-form estimates suggests that the implausibly large structural estimates are not simply an artifact of the complexities of the structural model; Section 5 further discusses potential explanations for these results.

Figure 1 provides additional insights into the drivers of the differences between the MPS and current estimates. Along with the current estimates (in red, labeled as \#1) and MPS central estimates (in blue, labeled as \#4), it plots estimates that we derived using the current cost function estimates and MPS demand elasticities (in green, labeled as \#2) and estimates that we derived using available MPS cost function coefficients and MPS demand elasticities (in orange, labeled as \#3). Note that the estimates in orange (\#3) are an approximation using sample average cost shares from the current estimation sample rather than the MPS sample averages because MPS did not report all of the average cost shares.

Using MPS demand elasticities substantially changed the total effect estimate for the paper industry and steel industry. In Table 5, the demand effect in column (7) is fairly similar between the MPS and current estimations. The similarity is perhaps surprising because of the large differences in 
demand elasticities reported in column (8). However, the demand effect depends on the demand elasticities, the cost shares, and $\alpha_{r}$. In this case, the differences happened to roughly cancel out, yielding similar demand effects. Therefore, differences in the MPS cost function estimates explain much of the difference in the employment effects (compare the red (\#1) and the orange (\#3) columns for the cost effect in each panel). Except for the steel industry, the differences in the total effect estimates that are due to differences in the sample average cost shares are also substantial.

\subsubsection{Additional Years and Industries}

Table 6 reports estimated employment effects based on all available years of data for the four MPS industries and an additional six industries. The table is structured similarly to Table 5 . The large positive effects for the plastics and steel industries in the structural model are similar to those observed in Table 5, though the reduced-form estimate for the plastics industry is much smaller. Several of the additional industries exhibit large and positive estimated total employment effects in the structural model: rolling and drawing, pipe fitting, miscellaneous wood, and other electrical equipment. However, the effect is statistically significant only for the rolling and drawing industry. In addition, we observed sizable differences between the reduced-form and structural estimates for the six new industries. Three of the six reduced-form estimates are large and negative, while their structural estimates are large and positive, although neither is statistically significant. The results of the reduced-form regressions were stable across several alternative model definitions ${ }^{10}$ for most industries and in all cases where we found statistically significant effects.

\section{DISCUSSION}

As reported in Section 4, we obtained different results when we estimated the employment effect of PAOC for the MPS industries, even when using the same years as MPS. Furthermore, for some industries and years we obtained implausibly large and positive estimates. We catalog a number of possible explanations for these results, although we are not able to provide a definitive explanation.

\subsection{Variable Construction}

Differences in variable construction could explain the differences between the current and MPS estimates in Table 5. We derived many variables from reported Census costs and values, and we had to construct appropriate price deflators from various sources. As Appendix B describes, we constructed variables somewhat differently from the MPS method because (1) after 1994, the MECS and PACE data were no longer collected in the same year (MPS relied on concurrent data), and (2) in recent years the Census Bureau has collected much less detailed data on materials. Consequently, the information needed to construct material price deflators was not fully available even for the original MPS industries, and for some of the additional industries such materials detail was never available. To test whether the new methodology affected the results, we constructed an alternative dataset that more closely followed the MPS methodology (see Appendix C). We re-estimated the models using these datasets, but still obtained results similar to those reported in Table 5, Panel B. We have concluded that the differences in variable construction are unlikely to explain much of the observed differences in Table 5.

\footnotetext{
${ }^{10}$ Along with the baseline reduced-form models, we estimated six other models that included leads and lags of PAOC-to-production cost ratio as well as leads and lags of log output.
} 


\subsection{Estimation Model}

The MPS estimation model included multiple equations, cross- and within-equation parameter restrictions, and was estimated by maximum likelihood. MPS estimated the model in Time Series Processor (TSP) software, but because TSP is no longer available to Census researchers, we implemented our current estimation in Stata. The original TSP programs were lost along with the archived data, but we were able to find a printout of one of the original TSP programs that covered some parts of the estimation. Using a set of synthetic data outside the Census, we compared the results obtained by the new Stata procedure and the original TSP program. We obtained similar, though not identical, coefficient estimates using the original TSP code and our code. Specifically, out of 45 estimated coefficients, 20 differed by at most 10 percent, and 32 differed by at most 30 percent. Of the remaining coefficients, 7 were time fixed effects, and nearly all of the rest were not statistically significant. We have concluded that our estimation model is similar, if not identical, to that used by MPS.

\subsection{Estimation Samples}

Table 7 compares our sample with the MPS sample in terms of sample sizes as well as labor cost and PAOC shares (the only summary statistics provided by MPS). We observe several differences. As noted earlier, the MPS paper industry definition excluded pulp mills while we included them, and the MPS steel industry included coke ovens while we excluded them, explaining some of the differences in sample size. ${ }^{11}$ Though labor shares for the petroleum and plastics industries were comparable for the two samples, labor shares for the paper and steel industries in our samples were about 50 percent and 30 percent lower than MPS. Finally, the PAOC share in our data was more than 50 percent smaller than the MPS PAOC share.

Differences in sample composition could arise for a variety of reasons, including data editing procedures that dropped some plants for missing or imputed values as well as changes in industry definitions. As discussed above, adopting the MPS SIC-based industry definitions did not substantially affect the results. There is no particular reason why differences in data editing or other aspects of sample construction would necessarily have resulted in substantial differences in the estimated results. Still, there are several possible reasons for different results for the two samples-they are not mutually exclusive, and their importance may differ across industries.

\subsubsection{Heterogeneous Cost Function}

If all plants had the same cost function parameters, changing the estimation sample would not be expected to result in substantially different coefficients. However, if the true parameters differed across plants, we could get different estimated parameters because the coefficient estimates would represent weighted averages of the plant-level parameters.

In fact, there is some indication that parameters may vary across plants. Plant age (as measured by a pre-1963 vintage dummy) significantly modifies the PAOC effect. We observed this modification for the petroleum and steel industries in the analyses using MPS years, and for all industries (except other electrical) in the analyses using the full range of years. While not conclusive,

\footnotetext{
${ }^{11}$ The summary statistics for the original MPS industry definitions are not available due to disclosure concerns.
} 
this modification suggested some heterogeneity in cost function parameters across plants that could have contributed to different estimates for the two samples.

\subsubsection{Sensitivity of Translog Cost Function to the Estimation Sample}

The model estimated here includes a nonlinear cost function with many parameter restrictions. In such cases, substantial differences in coefficient estimates can result from small changes in the estimation sample. This potential sensitivity motivated the reduced-form approach reported in Tables 5 and 6, which yielded the same qualitative results for the MPS industries and years. Reduced-form models designed to minimize the impact of outliers also yielded similar results. These tests suggest that sensitivity of the cost function to sample composition may not be an important factor in explaining the differences in Table 5.

\subsubsection{Endogeneity of PAOC and Other Variables}

Because plants choose PAOC simultaneously with other variables, PAOC may be correlated with unobserved and time-varying plant-specific variables. This might help explain the large positive effects that we often observed in our results. Because the same could be true for the MPS analysis, such endogeneity by itself cannot explain the differences between the MPS and current results. However, it is possible that endogeneity caused greater problems in our sample than it did for MPS, although there is no specific reason to expect this to happen.

As noted above, it is not feasible within the confines of this research to adapt the Olley-Pakes production function estimation approach to the MPS cost function model. Instead, we used the OlleyPakes production function model to investigate whether PAOC endogeneity was likely to explain the implausible results and the differences between the current and MPS estimates. If endogeneity were a concern, we would have expected to observe large within-plant variation in plant TFP, as estimated by the Olley-Pakes model. We compared the results of production function estimation with and without Olley-Pakes controls for endogeneity, without finding substantial differences. Table 8 shows the between- and within-plant variation on log-TFP that we generated using the Olley-Pakes model estimates (for samples including all available years of data). The within-plant variation was very close to the between-plant variation, which suggests that the plant fixed effects in the cost functions may not have fully controlled for plant-specific TFP. Table 8 also shows that the average estimated log-TFP declined over time for all industries.

In addition, we tried several instrumental variable (IV) versions of the reduced-form regression. We instrumented for PAOC using county-level dummy variables for non-attainment of National Ambient Air Quality Standards (NAAQS) and the League of Conservation Voters scorecard, which measures pro-environmental voting by the state's Congressional delegation. Unfortunately, neither of these instruments provided much explanatory power in the first stage, rendering the IV results effectively unusable (Bound, Jaeger, and Baker, 1995). ${ }^{12}$

\footnotetext{
${ }^{12}$ The first stage F-tests showed that dummy variables for county-level NAAQS non-attainment and the League of Conservation Voters scorecard were not statistically significant predictors of PAOC-to-production cost ratio for all industries and samples except the steel industry (all years sample) and the other electrical industry (all years sample). In both of these cases, the $\mathrm{R}^{2}$ values were less than 1 percent, and the magnitude of the
} 
It is also possible that multi-plant firms try to retain their labor by moving the employees around whenever there is a plant closure. Because we restricted the structural model estimation to plants that were continuing, these cross-plant spillovers might have confounded the PAOC effects if PAOC were correlated with the exit of other plants owned by the same firm. To examine this possibility, we created a variable that measured the potential spillover effects. The spillovers can occur only at plants belonging to multi-plant firms, and are related to the number of employees released by closing plants. We measured the magnitude of potential spillover to a plant in year $t$ as the fraction of the firm's employment in year $t-5$ at plants that are no longer in operation by year $t$. This number was zero if none of the firm's plants closed between year $t-5$ and year $t$ (no spillovers possible) and approached one if nearly all of the firm's plants closed during these five years.

We included the spillover measure as a regressor in the reduced-form regressions. We observed reductions in the magnitudes of the estimated PAOC effects for the paper, plastics, steel, pipe fitting, Portland cement industries, miscellaneous wood products (with a change in sign), and other electrical industry, but the effects of PAOC in the petroleum, pharmaceuticals, and rolling and drawing industries were similar to the baseline estimates. The spillover measure itself was not significant, but the results suggested that in many industries some employment was reallocated from exiting plants to continuing plants, possibly helping to explain the estimated positive employment effects from the structural model.

In sum, we examined a multitude of possibilities for the large estimated employment effects and the differences relative to MPS. Only two explanations were not rejected: heterogeneity of the cost function and endogeneity of PAOC.

\section{CONCLUSION}

Research on the link between environmental regulation and jobs is particularly challenging because of the difficulty of disentangling the effects of regulation from other key determinants of employment. Similar to other recent papers, the present analysis used plant-level information based on confidential Census data. The principal emphasis here was on a structural, as opposed to a reducedform, model for continuing (non-exiting) plants, which allowed a decomposition of total employment effects into the cost, factor, and demand effects. We focused on net, as opposed to gross, job impacts within an industry. The metric of regulation, PAOC, is derived from the PACE survey, the most comprehensive source of pollution abatement costs and expenditures available. The data span more than 30 years, including the most recent information collected (2005), and cover 10 industries that have high levels of pollution abatement costs.

In many cases, we found implausibly large positive employment effects of abatement expenditures. For 6 of our 10 industries the structural model indicated total effects of 10-30 additional employees hired for each $\$ 1$ million in additional abatement expenditures. This would imply that nearly all abatement spending is on labor, which is inconsistent with the observed capital intensity of abatement technologies. Using both reduced-form and structural models, we saw relatively similar results for the four MPS industries. In contrast, the other six industries showed considerable differences between the two modeling approaches, with some large positive structural estimates paired with large negative reduced-form estimates. Our results also tended to be substantially larger

instrumented PAOC impact was similar to that of the un-instrumented PAOC (for the steel industry this effect turned insignificant in the IV runs). 
than the original MPS results. We explored several possible explanations for this difference without reaching a satisfactory conclusion. The surprisingly large positive effects overall might be due to endogeneity of PAOC, but our attempts to test for endogeneity with an instrumental variables approach failed due to a lack of valid instruments. Given these concerns, even the effects that are plausible in themselves should probably not be taken too seriously.

Finally, we address the issue of applying modeling results such as these to Regulatory Impact Analyses (RIAs) for new environmental rules. The application of analytical results from one situation to other, less studied areas is fairly routine, such as the use of benefits transfer in valuing environmental damages. However, the wide range of estimated values across industries observed here makes such an approach questionable. We emphasize the importance of making appropriate comparisons in RIAs, where the industry from which the estimates are derived is comparable to the one covered by the new rule and the impact of the new regulation on the production process is roughly comparable to the historical pattern of regulatory costs imposed on that industry. Even the smaller effects in the original MPS paper, which covered only the period 1979-91, showed considerable variability. Thus, using their average value to generate quantitative estimates of the employment effects of new rules in different industries is problematic. Specifically, even beyond the variability among the four principal industries, MPS found even larger differences between those four and a group of six additional industries for which the authors were unable to develop credible cost function estimates. For the four principal industries, MPS developed confidence intervals that included both positive and negative results in two cases. Thus, even without the additional results we report herein, the use of the original MPS results in RIAs would be questionable, especially without adequate qualification capturing the inherent uncertainty of the results. Now, with the added uncertainty introduced by the present results, the use of the work in RIAs is even more questionable. 


\section{REFERENCES}

Bartelsman, E. J., and W. B. Gray. 1994. NBER Productivity Database [online]. URL: http://www.nber.org/nberces/.

Becker, Randy A., and J. Vernon Henderson. 2000. "Effects of Air Quality Regulations on Polluting Industries." Journal of Political Economy 108(2): 379-421.

Becker, Randy, and Ronald Shadbegian. 2007. "Issues and Challenges in Measuring Environmental Expenditures by U.S. Manufacturing: The Redevelopment of the PACE Survey." NCEE Working Paper Number 2007-08, July.

Bender, R., and S. Lange. 2001. "Adjusting for Multiple Testing-When and How?" J. Clin. Epidemiol. 54(4): 343-349.

Berman, Eli, and Linda T. Bui. 2001. "Environmental Regulation and Productivity: Evidence from Oil Refineries," The Review of Economics and Statistics 83(3): 498-510.

Bound, J., David A. Jaeger, and R.M. Baker. 1995. "Problems with Instrumental Variables Estimation When the Correlation Between the Instruments and the Endogenous Explanatory Variable Is Weak." Journal of the American Statistical Association 90(430) (June 1995): 443-450.

Caves, D.W., L. R. Christensen, and W. E. Diewert. 1982a. "The Economic Theory of Index Numbers and the Measurement of Input, Output, and Productivity." Econometrica 50(6): 1393-1414.

Caves, D.W., L. R. Christensen, and W. E. Diewert. 1982b. "Multilateral Comparisons of Output, Input and Productivity Using Superlative Index Numbers." Economic Journal 92: 73-86.

Christensen, L., and D. Jorgenson. 1969. "The Measurement of U.S. Real Capital Input, 19291967." Review of Income and Wealth, 293-320.

Davis, Steven, John Haltiwanger, and Scott Schuh. 1998. Job Creation and Destruction. MIT Press.

Foster, Lucia, John Haltiwanger, and Chad Syverson. 2008. "Reallocation, Firm Turnover, and Efficiency: Selection on Productivity or Profitability?” American Economic Review 98(1): 394-425.

Gallaher, Michael P., Cynthia L. Morgan, and Ronald J. Shadbegian. 2008. "Redesign of the 2005 Pollution Abatement Costs and Expenditure Survey." Journal of Economic and Social Measurement 33(4): 309-360.

Gray, Wayne, and Ronald J. Shadbegian. 2002. "Pollution Abatement Costs, Regulation, and Plant-Level Productivity" in The Economic Costs and Consequences of Environmental Regulation, W.B. Gray, ed. Ashgate Publications, 2002.

Greenstone, Michael. 2002. "The Impacts of Environmental Regulations on Industrial Activity: Evidence from the 1970 and 1977 Clean Air Act Amendments and the Census of Manufactures." Journal of Political Economy 110(6): 175-1219. 
Greenstone, Michael, John A. List, and Chad Syverson. 2011. "The Effects of Environmental Regulation on the Competitiveness of U.S. Manufacturing." U.S. Census Bureau Center for Economic Studies Paper No. CES-WP-11-03.

Hanna, Rema. 2010. "US Environmental Regulation and FDI: Evidence from a Panel of US Based Multinational Firms." American Economic Journal: Applied Economics 2(3): 158-189.

Henderson, J. Vernon. 1996. "Effects of Air Quality Regulation." American Economic Review 86(4): 789-813.

Holm, S. 1979. "A Simple Sequentially Rejective Multiple Test Procedure." Scandinavian Journal of Statistics 6:65-70.

Hulten, C. R., and F. C. Wykoff. 1981. "The Measurement of Economic Depreciation." In C. R. Hulten, ed., Depreciation, Inflation, and the Taxation of Income from Capital. Washington, DC: Urban Institute Press.

Jarmin, Ron S., and Javier Miranda. 2002. "The Longitudinal Business Database." Center for Economic Studies Discussion Paper CES-WP-02-17.

Jorgenson, Dale W. 1990. "Productivity and Economic Growth." In Ernst R. Berndt and Jack E. Triplett, eds., Fifty Years of Economic Measurement: The Jubilee Conference on Research in Income and Wealth. Chicago, IL: University of Chicago Press.

Jorgenson, Dale W., Frank M. Gollop, and Barbara M. Fraumeni. 1987. Productivity and U.S. Economic Growth. Cambridge, MA: Harvard University Press.

Jorgenson, Dale W., and Kevin J. Stiroh. 2000. "Raising the Speed Limit: U.S. Economic Growth in the Information Age." Brookings Papers on Economic Activity 1: 125-211.

Joshi, S.L., L. Lave, J.-S. Shih, and F. McMichael. 1997. "Impact of Environmental Regulations on the U.S. Steel Industry." Mimeo. Carnegie Mellon University.

Keller, W., and A. Levinson. 2002. "Pollution Abatement Costs and Foreign Direct Investment Inflows to U.S. States." Review of Economics and Statistics 84:691-703.

Morgenstern, Richard D., William A. Pizer, and Jhih-Shang Shih. 2001. "The Cost of Environmental Protection." Review of Economics and Statistics 83 (4): 732-738. (An RFF Discussion Paper version from 1998 providing more information, including a discussion of the seven smaller industries, is available at: http://www.rff.org/RFF/Documents/RFF-DP-98-36.pdf.)

Morgenstern, Richard D., William A. Pizer, and Jhih-Shang Shih. 2002. "Jobs Versus the Environment: An Industry-Level Perspective." Journal of Environmental Economics and Management 43:412-436.

Olley, S., and A. Pakes. 1996. "The Dynamics of Productivity in the Telecommunications Equipment Industry." Econometrica 64(6):1263-1297.

Petrin, A., and F. Warzynski. 2012. "The Impact of Research and Development on Quality, Productivity, and Welfare." Mimeo, University of Minnesota. 
Becker, Randy A., and Ronald J. Shadbegian. "A change of PACE: Comparing the 1994 and 1999 Pollution Abatement Costs and Expenditures surveys." Journal of Economic and Social Measurement 30.1 (2005): 63-95.

Xing, Y., and C. Kolstad. 2002. “Do Lax Environmental Regulations Attract Foreign Investment?" Environmental and Resource Economics 21:1-22. 


\section{Appendix A: The Production Cost Model}

MPS developed an expression for the entire employment effect,

$$
\frac{\partial L_{a g g}}{\partial R C_{a g g}}=\underbrace{\frac{1}{T C_{a g g}} \sum_{i=1}^{I} \frac{T C_{i}^{\eta}}{P_{l i}} \frac{\partial v_{l, i}}{\partial R C_{i}}}_{\text {Factor Shift }}+\underbrace{\frac{\partial T C}{\partial R C} \frac{L_{a g g}}{T C_{a g g}}}_{\text {Cost Effect }}+\underbrace{\left(-\sigma_{d d}\right) \frac{\partial T C}{\partial R C} \frac{L_{a g g}}{T C_{a g g}}}_{\text {Demand Effect }}
$$

where $L_{a g g}$ is aggregate industry employment, $R C_{a g g}$ is the aggregate dollar measure of regulatory burden (PAOC) in the industry, $T C_{\text {agg }}$ is the total industry-wide cost (including both conventional production and regulatory costs), $v_{l, i}$ is the labor cost share and $P_{l, i}$ is the wage at plant $i$, and $-\sigma_{d}$ is the industry-level demand elasticity. Unlike equations in studies that focus solely on negative demand effects, equation (A1) explicitly allows for supply-side labor effects that may offset any industry-wide contraction. Equation (A1) also allows one to consider each piece of the employment effect separately, assess its economic and statistical significance, and potentially design policy to properly address labor and industry concerns. Evaluation of this expression requires estimates of a structural model of production costs along with an industry-level demand elasticity.

The cost model is based on the assumption that the production of non-environmental outputs and environmental activities are distinct and are described by separate cost functions. Specifically, $P C=G\left(Y, \mathbf{P}_{i} i, t\right)$ describes the cost $(P C)$ of producing non-environmental output $Y$ based on input price vector $\mathbf{P}$ at plant $i$ at time $t$. Similarly, let $R C=H(R, \mathbf{P}, i, t)$ describe the cost $(R C)$ of producing environmental "output" $R$ similarly based on input price vector $\mathbf{P}$ at plant $i$ at time $t$. Inputs include capital, labor, energy, and materials.

MPS allowed for the possibility that these two activities are not, in fact, distinct by rewriting $P C=G\left(Y, P_{j}, i, t\right)[f(R C)]{ }^{\alpha_{r}}$ where $f(R C)$ is an increasing function of regulatory expenditure. The parameter $\alpha_{r}$ describes the degree of interaction. A zero value indicates no significant interaction, negative values indicate cost savings, and positive values indicate additional burden.

MPS chose the following translog parameterization for $G($.$) and H($.$) :$

$$
\begin{aligned}
& \ln P C=\alpha_{i}+\alpha_{t}+\alpha_{i, p}^{\prime} \ln \mathbf{P}+\alpha_{y} \ln Y+\frac{1}{2} \ln \mathbf{P}^{\prime} \beta_{p p} \ln \mathbf{P} \\
& +\frac{1}{2} \beta_{y}(\ln Y)^{2}+\beta_{t, p} \ln \mathbf{P}+\beta_{y p} \ln Y \ln \mathbf{P}+\beta_{y t} t \cdot Y+\alpha_{r} \frac{R C}{P C} \\
& \ln R C=\gamma+\gamma_{r} \ln R+\gamma_{p}^{\prime} \ln \mathbf{P}+\frac{1}{2} \ln \mathbf{P}^{\prime} \delta_{p p} \ln \mathbf{P}+\gamma_{t} t+\delta_{p t}^{y} \ln \mathbf{P} \cdot t
\end{aligned}
$$

where $\mathbf{P}$ is a vector of input prices (capital, labor, energy, and materials), $P C$ are costs related to non-environmental output $Y, R C$ are costs related to environmental output $R$, and $t$ is time. The parameters have the following interpretations: $\alpha_{i}$ are plant-specific, Hicks-neutral productivity effects; $\alpha_{t}$ are time dummies, capturing aggregate Hicks-neutral productivity trends; $\alpha_{i, p}$ are vectors of plantspecific cost-share parameters; $\boldsymbol{\beta}_{p p}$ is a matrix of share elasticities; $\alpha_{y}$ and $\beta_{y}$ capture scale economies; $\boldsymbol{\beta}_{t, p}$ are year-specific productivity biases; $\boldsymbol{\beta}_{y p}$ reflects biases of scale; and $\beta_{y t}$ captures any aggregate time trend in scale economies. All of these parameters refer to non-environmental production. The environmental production parameters have the following interpretations: $\gamma_{p}$ is a 
vector of aggregate cost share parameters; $\delta_{p p}$ is a matrix of share elasticities; $\gamma_{t}$ describes the Hicksneutral productivity trend; and $\delta_{p t}$ captures factor trends. Finally, $\alpha_{r}$ describes any interaction between environmental and non-environmental activities.

The standard approach to estimate models such as those described in equations (A2) and (A3) is to specify a system of cost shares based on the first derivatives with respect to log prices. Stochastic disturbances are appended to each equation, and the system is estimated simultaneously (with crossequation restrictions) in order to improve efficiency. The problem with this approach in the current context is that factor inputs used for environmental activities cannot be distinguished from those used for conventional production; and we have no direct measure of $R$, environmental output. Since factor inputs cannot be disaggregated in the data, the cost shares associated with equations (A2) and (A3) are not observed. Further, since there is no direct measure of $R$, equation (A3) cannot be estimated.

MPS circumvented these problems by assuming homothetic environmental costs $H($.). Environmental cost shares were solely a function of input prices and time (and not $R$ ):

$$
\begin{aligned}
& v_{k, r}=\gamma_{k}+\delta_{k}^{l} \ln \mathbf{P}+\delta_{k t} t \\
& v_{l, r}=\gamma_{l}+\delta_{l}^{t} \ln \mathbf{P}+\delta_{l t} t \\
& v_{e, r}=\gamma_{e}+\delta_{e}^{v} \ln \mathbf{P}+\delta_{e t} t \\
& v_{m, r}=\gamma_{m}+\delta_{m}^{v} \ln \mathbf{P}+\delta_{m t} t
\end{aligned}
$$

Coupled with non-environmental cost shares derived from equation (A2),

$$
\begin{aligned}
& v_{k, y}=\alpha_{i, k}+\beta_{k}^{\prime} \ln \mathbf{P}+\beta_{y k} \ln Y+\beta_{t, k} \\
& v_{l y}=\alpha_{i, l}+\boldsymbol{\beta}_{l}^{\prime} \ln \mathbf{P}+\beta_{y l} \ln Y+\beta_{t_{l} l} \\
& v_{\theta, y}=\alpha_{i_{i} e}+\beta_{\theta}^{\gamma} \ln \mathbf{P}+\beta_{y e} \ln Y+\beta_{t_{i} e} \\
& v_{m y}=\alpha_{i, m}+\beta_{m}^{v} \ln \mathbf{P}+\beta_{y m} \ln Y+\beta_{t, m}
\end{aligned}
$$

the observed total cost shares can be written as

$$
\begin{aligned}
& v_{k}=\frac{R C}{P C+R C} v_{k, r}+\left(1-\frac{R C}{P C+R C}\right) v_{k, y} \\
& v_{l}=\frac{R C}{P C+R C} v_{l, r}+\left(1-\frac{R C}{P C+R C}\right) v_{l y y}
\end{aligned}
$$




$$
\begin{aligned}
& v_{e}=\frac{R C}{P C+R C} v_{\theta_{0},}+\left(1-\frac{R C}{P C+R C}\right) v_{e, y} \\
& v_{m}=\frac{R C}{P C+R C} v_{m, r}+\left(1-\frac{R C}{P C+R C}\right) v_{m, y}
\end{aligned}
$$

These aggregate cost shares (over both non-environmental and environmental expenditures) are observable themselves and depend on other observable variables (prices, output, time, and regulation as a share of total costs). The equations in (A6) can therefore be estimated alongside the production cost function (A2) by treating each as a stochastic relation and adding random disturbances.

Because the endogenous variable $P C$ appears on the right-hand side of the production cost function and aggregate share equations, MPS used a two-step approach. They first estimated the system of equations, setting $R C=0$ (which eliminates $P C$ on the right-hand side as well as the regulatory cost share parameters $\gamma$ and $\delta$ ). MPS used these parameter estimates to construct exogenous predicted values of $\overrightarrow{P C}$ to replace the actual values of $P C$ on the right-hand side of equations (A2) and (A6). MPS then used these predicted values to re-estimate the system without the endogeneity problem. At both estimation stages, MPS imposed symmetry $\left(\beta_{i j}=\beta_{j i}\right.$ and $\left.\delta_{i j}=\delta_{j i}\right)$ and homogeneity of degree one in prices (which allowed us to arbitrarily drop a share equation). MPS used a maximum likelihood estimator that iterated on the covariance matrix estimate until it converged. 


\section{Appendix B: Census Microdata and Summary Statistics}

We used the Longitudinal Business Database (LBD), as described in Jarmin and Miranda 2002) ${ }^{13}$ to link data from the Annual Survey of Manufactures (ASM) and the Census of Manufactures (CM) to form a panel of plant-level data that includes costs, outputs, and inputs. More than 50,000 establishments are included each year, with a census of all plants occurring every 5 years. We obtained data on energy prices and quantities from the Manufacturing Energy Consumption Survey (MECS), collected by the Census Bureau for the Department of Energy every three years, beginning in 1985. Our measure of regulatory pressure came from the Pollution Abatement Costs and Expenditures (PACE) survey, collected annually by the Census Bureau from 1973 to 1994 (with two exceptions) but conducted only twice since then (1999 and 2005). We linked these plant-level data with other data (described below) to create the dataset we used in our analysis.

Because our work expanded that of MPS, our data construction process was similar to theirs. However, our expansion of the data to cover additional industries and additional years forced some modifications to the MPS process. First, MPS restricted their sample to years in which both the MECS and PACE surveys were collected, but none of the recent PACE years coincided with a MECS survey. We modified the construction of plant-level energy prices to allow us to work with non-MECS years, which greatly expanded our sample years - although most of those additional years fall in the 1974-1994 period. Second, MPS relied on material-specific quantity data collected by the Census to calculate their materials price deflators. Below we describe our approach for constructing materials prices. Our measure of plant output came from the value of shipments as reported in the Longitudinal Research Database, adjusted for inventory changes. The LRD also provided a breakdown of the total value of shipments into the values produced of each specific product, which we combined with the corresponding producer price indices (PPIs) from the Bureau of Labor Statistics (BLS) to form a plantspecific divisia index of output prices. We were able to get BLS PPI records to match the product categories almost perfectly. Labor input also came from the LRD, measured as the number of production workers and with the corresponding price index defined as labor cost (production worker wages plus their share of supplemental labor cost) per production worker. The "share" of supplemental labor cost is calculated from the share of production worker wages in total wages.

The LRD provided data on the plant's energy spending, distinguishing between electricity and fuels and including the quantity of electricity purchased. In a few years (1979-1981) the LRD also provided separate cost and quantity data for several different fuel types, while more recently those data have been provided by the MECS. We first calculated plant-specific deflators for fuel prices and their cost shares for the MECS years. Then we used state-specific fuel prices from the SEDS (State Energy Data System from the Department of Energy) database to interpolate the changes in a plant's fuel prices between the MECS years. ${ }^{14}$ The plant-specific price of energy is a divisia index of the prices of these fuels and electricity (for which we have plant- and year-specific information).

The LRD provided expenditure data on total materials spending, as well as a breakdown of expenditures on specific materials every five years, at the time of Economic Census. For some materials, these data included the quantity of the material used, which MPS used to calculate a plantspecific materials price deflator. Unfortunately, in recent years the Census has dramatically reduced

\footnotetext{
${ }^{13}$ MPS used the manufacturing-only Longitudinal Research Database (LRD), the precursor to the LBD.

${ }^{14}$ The SEDS data are available at http://www.eia.gov/state/seds/.
} 
the number of materials for which the quantity data are collected, even for the MPS industries. There are also some differences in the definitions of materials reported before and after 1997. Furthermore, the quantity data are not available for some of the additional industries in our sample for any of the years. These factors forced us to modify the construction of plant-specific materials price deflators. We used the Census material expenditure data to calculate plant-specific average cost shares for each reported material over the 1977-1997 period (up to five Census years of data) and used the cost shares to weight the corresponding producer prices from BLS. For those materials where BLS producer prices were not available, we used the industry-specific materials cost deflator from the Manufacturing Productivity Database as a substitute. To maintain consistency across industries and years, we used the modified deflators for all our analyses (for the MPS years and industries, the results were similar using the MPS methodology and the current methodology).

For capital input, the LRD provided annual data on new capital expenditures and some data on the (nominal) gross book value of a plant's capital stock, but these needed to be combined with other data to generate a measure of real capital stocks and capital services prices. We used the LRD-linked database created by John Haltiwanger for the real capital stock for each plant. Like the data in MPS, our capital services price data are not plant-specific. We took the corresponding capital services price series from the 35-KLEM sectoral input-output database for 1960-2005, developed by Dale Jorgenson and described in Jorgenson and Stiroh (2000), Jorgenson (1990), and Jorgenson, Gollop and Fraumeni (1987). We then calculated the plant's annual capital expenditures as the product of the capital services price and the plant's real capital stock.

The PACE survey provided our plant-specific measure of annual pollution abatement operating costs. These costs included costs for depreciation of the plant's stock of pollution abatement capital, and provided a relatively comprehensive measure of abatement costs. Since these were nominal data, we deflated them by the GDP deflator to generate a measure of real regulatory expenditure. The expansion of the MPS data to more recent years was limited by the availability of the PACE survey. We are aware that the 1999 PACE survey questionnaire was significantly different from the questionnaire in other years, as discussed in Becker and Shadbegian (2005). Some categories of abatement costs (e.g., depreciation) were not included in the 1999 PACE, while other previously separate categories (e.g., pollution prevention operating costs and capital expenditures) were combined, leading to potential difficulties in comparing costs across years. However, ignoring the 1999 PACE would create a decade-long gap in plant-level abatement cost data. We made plant-specific imputations (based on values reported in other PACE years) to fill in the missing categories of abatement costs. We also tested whether excluding 1999 from the analysis affected the overall results; doing so did not have a large impact. 
Appendix Table B1. Summary Statistics

\begin{tabular}{|c|c|c|c|c|c|c|c|c|c|c|c|c|c|c|c|}
\hline \multicolumn{2}{|c|}{ Industry: } & Paper & Petroleum & Plastics & Steel & Paper & Petroleum & Plastics & Steel & $\begin{array}{l}\text { Portland } \\
\text { Cement }\end{array}$ & $\begin{array}{l}\text { Rolling and } \\
\text { Drawing }\end{array}$ & Pipe Fitting & $\begin{array}{l}\text { Misc. Wood } \\
\text { Products }\end{array}$ & $\begin{array}{l}\text { Pharmaceut } \\
\text { icals }\end{array}$ & $\begin{array}{c}\text { Other } \\
\text { Electrical } \\
\text { Equipment }\end{array}$ \\
\hline \multicolumn{2}{|c|}{ Years: } & \multicolumn{4}{|c|}{ MPS years $(1979,1980,1981,1985,1988,1991)$} & \multicolumn{10}{|c|}{ All years (1976-1982, 1984-1986, 1988-1994 1999, and 2005) } \\
\hline \multicolumn{2}{|c|}{$\mathbf{N}$} & 824 & 697 & 548 & 486 & 2928 & 2263 & 2515 & 1639 & 1032 & 1388 & 868 & 922 & 1579 & 1805 \\
\hline Variable & Units & \multicolumn{14}{|c|}{ Sample average (Sample Standard Deviation) } \\
\hline Output & $\begin{array}{c}\text { Thous. 1997\$ } \\
\text { / year }\end{array}$ & $\begin{array}{c}210,373 \\
(145,441)\end{array}$ & $\begin{array}{c}953,256 \\
(958,534)\end{array}$ & $\begin{array}{c}232,197 \\
(253,175)\end{array}$ & $\begin{array}{c}524,634 \\
(673,167)\end{array}$ & $\begin{array}{c}210,875 \\
(157,888)\end{array}$ & $\begin{array}{c}1,111,850 \\
(1,157,384)\end{array}$ & $\begin{array}{c}222,236 \\
(265,527)\end{array}$ & $\begin{array}{c}552,207 \\
(724,773)\end{array}$ & $\begin{array}{c}56,714 \\
(32,710)\end{array}$ & $\begin{array}{c}139,213 \\
(147,954)\end{array}$ & $\begin{array}{c}80,820 \\
(426,528)\end{array}$ & $\begin{array}{c}64,043 \\
(133,523)\end{array}$ & $\begin{array}{c}595,818 \\
(796,132)\end{array}$ & $\begin{array}{c}106,867 \\
(113,211)\end{array}$ \\
\hline Capital stock & Thous. 1997\$ & $\begin{array}{c}147,846 \\
(151,894)\end{array}$ & $\begin{array}{c}306,495 \\
(352,024)\end{array}$ & $\begin{array}{c}135,611 \\
(156,741)\end{array}$ & $\begin{array}{c}347,967 \\
(544,262)\end{array}$ & $\begin{array}{c}167,801 \\
(195,945)\end{array}$ & $\begin{array}{c}348,817 \\
(438,581)\end{array}$ & $\begin{array}{c}127,884 \\
(162,508)\end{array}$ & $\begin{array}{c}370,950 \\
(556,506)\end{array}$ & $\begin{array}{c}58,416 \\
(71,532)\end{array}$ & $\begin{array}{c}37,622 \\
(55,047)\end{array}$ & $\begin{array}{c}19,964 \\
(19,278)\end{array}$ & $\begin{array}{c}10,976 \\
(27,827)\end{array}$ & $\begin{array}{c}136,194 \\
(232,829)\end{array}$ & $\begin{array}{c}28,446 \\
(49,340)\end{array}$ \\
\hline Energy & $\begin{array}{c}\text { Thous. 1997\$ } \\
\text { / year }\end{array}$ & $\begin{array}{c}18,019 \\
(15,418)\end{array}$ & $\begin{array}{c}32,507 \\
(60,796)\end{array}$ & $\begin{array}{c}10,624 \\
(10,803)\end{array}$ & $\begin{array}{c}45,806 \\
(70,110)\end{array}$ & $\begin{array}{c}16,630 \\
(14,532)\end{array}$ & $\begin{array}{c}33,162 \\
(63,856)\end{array}$ & $\begin{array}{c}9,404 \\
(13,377)\end{array}$ & $\begin{array}{c}43,049 \\
(68,880)\end{array}$ & $\begin{array}{l}10,023 \\
(7,663)\end{array}$ & $\begin{array}{c}2,492 \\
(2,757)\end{array}$ & $\begin{array}{c}917 \\
(1,186)\end{array}$ & $\begin{array}{c}422 \\
(698)\end{array}$ & $\begin{array}{l}4,459 \\
(7,851)\end{array}$ & $\begin{array}{c}1,409 \\
(1,301)\end{array}$ \\
\hline Employment & $\begin{array}{c}\text { Production } \\
\text { workers }\end{array}$ & $\begin{array}{c}580 \\
(406)\end{array}$ & $\begin{array}{c}373 \\
(364)\end{array}$ & $\begin{array}{l}557 \\
(627)\end{array}$ & $\begin{array}{c}1,985 \\
(2,696)\end{array}$ & $\begin{array}{c}543 \\
(402)\end{array}$ & $\begin{array}{c}360 \\
(350)\end{array}$ & $\begin{array}{c}414 \\
(539)\end{array}$ & $\begin{array}{c}1,803 \\
(2,453)\end{array}$ & $\begin{array}{l}140 \\
(84)\end{array}$ & $\begin{array}{c}376 \\
(361)\end{array}$ & $\begin{array}{c}349 \\
(296)\end{array}$ & $\begin{array}{c}340 \\
(502)\end{array}$ & $\begin{array}{l}512 \\
(592)\end{array}$ & $\begin{array}{c}414 \\
(422)\end{array}$ \\
\hline Materials & $\begin{array}{c}\text { Thous. } 1997 \$ \\
\text { / year }\end{array}$ & $\begin{array}{c}66,036 \\
(40,250)\end{array}$ & $\begin{array}{c}756,845 \\
(741,082)\end{array}$ & $\begin{array}{l}108,559 \\
(85,988)\end{array}$ & $\begin{array}{c}210,829 \\
(273,243)\end{array}$ & $\begin{array}{c}67,618 \\
(47,334)\end{array}$ & $\begin{array}{c}764,532 \\
(739,283)\end{array}$ & $\begin{array}{c}103,095 \\
(103,653)\end{array}$ & $\begin{array}{c}213,142 \\
(266,020)\end{array}$ & $\begin{array}{c}7,492 \\
(4,981)\end{array}$ & $\begin{array}{c}62,263 \\
(70,741)\end{array}$ & $\begin{array}{c}17,035 \\
(16,314)\end{array}$ & $\begin{array}{c}24,828 \\
(50,265)\end{array}$ & $\begin{array}{c}72,145 \\
(152,755)\end{array}$ & $\begin{array}{c}35,882 \\
(38,306)\end{array}$ \\
\hline $\begin{array}{l}\text { Capital price } \\
\text { index }\end{array}$ & Base $=1997$ & $\begin{array}{c}0.66 \\
(0.18)\end{array}$ & $\begin{array}{c}0.97 \\
(0.14)\end{array}$ & $\begin{array}{c}0.52 \\
(0.16)\end{array}$ & $\begin{array}{c}0.53 \\
(0.10)\end{array}$ & $\begin{array}{c}0.72 \\
(0.20)\end{array}$ & $\begin{array}{c}0.96 \\
(0.61)\end{array}$ & $\begin{array}{c}0.64 \\
(0.20)\end{array}$ & $\begin{array}{c}0.60 \\
(0.30)\end{array}$ & $\begin{array}{c}0.77 \\
(0.29)\end{array}$ & $\begin{array}{c}0.58 \\
(0.29)\end{array}$ & $\begin{array}{c}0.53 \\
(0.17)\end{array}$ & $\begin{array}{c}0.76 \\
(0.26)\end{array}$ & $\begin{array}{c}0.62 \\
(0.22)\end{array}$ & $\begin{array}{c}0.56 \\
(0.17)\end{array}$ \\
\hline $\begin{array}{l}\text { Energy price } \\
\text { index }\end{array}$ & Base $=1997$ & $\begin{array}{c}0.91 \\
(0.44)\end{array}$ & $\begin{array}{c}0.95 \\
(0.64)\end{array}$ & $\begin{array}{c}0.94 \\
(0.44)\end{array}$ & $\begin{array}{c}0.99 \\
(0.63)\end{array}$ & $\begin{array}{c}0.96 \\
(0.55)\end{array}$ & $\begin{array}{c}0.96 \\
(0.61)\end{array}$ & $\begin{array}{c}0.96 \\
(0.41)\end{array}$ & $\begin{array}{c}0.98 \\
(0.56)\end{array}$ & $\begin{array}{c}1.03 \\
(0.48)\end{array}$ & $\begin{array}{c}0.90 \\
(0.36)\end{array}$ & $\begin{array}{c}0.91 \\
(0.28)\end{array}$ & $\begin{array}{c}0.96 \\
(0.31)\end{array}$ & $\begin{array}{c}0.93 \\
(0.41)\end{array}$ & $\begin{array}{c}0.93 \\
(0.37)\end{array}$ \\
\hline $\begin{array}{l}\text { Production } \\
\text { labor cost }\end{array}$ & $\begin{array}{c}\text { Thous. 1997\$ } \\
\text { / worker }\end{array}$ & $\begin{array}{c}35.98 \\
(10.48)\end{array}$ & $\begin{array}{c}39.66 \\
(10.79)\end{array}$ & $\begin{array}{c}33.94 \\
(11.39)\end{array}$ & $\begin{array}{c}39.26 \\
(10.01)\end{array}$ & $\begin{array}{c}40.22 \\
(16.30)\end{array}$ & $\begin{array}{c}44.02 \\
(22.28)\end{array}$ & $\begin{array}{c}40.88 \\
(19.00)\end{array}$ & $\begin{array}{c}42.07 \\
(16.24)\end{array}$ & $\begin{array}{c}39.31 \\
(12.46)\end{array}$ & $\begin{array}{c}27.92 \\
(11.93)\end{array}$ & $\begin{array}{c}26.85 \\
(10.94)\end{array}$ & $\begin{array}{l}21.94 \\
(9.92)\end{array}$ & $\begin{array}{c}33.59 \\
(17.99)\end{array}$ & $\begin{array}{c}26.82 \\
(12.59)\end{array}$ \\
\hline $\begin{array}{l}\text { Materials } \\
\text { price index }\end{array}$ & Base $=1997$ & $\begin{array}{c}0.94 \\
(0.12)\end{array}$ & $\begin{array}{c}1.17 \\
(0.29)\end{array}$ & $\begin{array}{c}0.99 \\
(0.12)\end{array}$ & $\begin{array}{c}0.96 \\
(0.10)\end{array}$ & $\begin{array}{c}0.97 \\
(0.19)\end{array}$ & $\begin{array}{c}1.10 \\
(0.40)\end{array}$ & $\begin{array}{c}1.00 \\
(0.21)\end{array}$ & $\begin{array}{c}0.95 \\
(0.17)\end{array}$ & $\begin{array}{c}1.00 \\
(0.20)\end{array}$ & $\begin{array}{c}0.98 \\
(0.23)\end{array}$ & $\begin{array}{c}0.94 \\
(0.20)\end{array}$ & $\begin{array}{c}0.96 \\
(0.22)\end{array}$ & $\begin{array}{c}0.94 \\
(0.22)\end{array}$ & $\begin{array}{c}0.98 \\
(0.21)\end{array}$ \\
\hline PAOC & $\begin{array}{c}\text { Thous. 1997\$ } \\
\text { / year }\end{array}$ & $\begin{array}{c}3,469 \\
(3,886)\end{array}$ & $\begin{array}{c}11,524 \\
(19,394)\end{array}$ & $\begin{array}{c}2,103 \\
(2,806)\end{array}$ & $\begin{array}{c}7,900 \\
(13,644)\end{array}$ & $\begin{array}{c}3,532 \\
(4,051)\end{array}$ & $\begin{array}{c}13,236 \\
(22,139)\end{array}$ & $\begin{array}{c}2,387 \\
(4,117)\end{array}$ & $\begin{array}{c}8,421 \\
(14,326)\end{array}$ & $\begin{array}{c}1,227 \\
(1,162)\end{array}$ & $\begin{array}{c}374 \\
(786)\end{array}$ & $\begin{array}{c}136 \\
(243)\end{array}$ & $\begin{array}{c}140 \\
(342)\end{array}$ & $\begin{array}{c}1,458 \\
(2,927)\end{array}$ & $\begin{array}{c}244 \\
(414)\end{array}$ \\
\hline $\begin{array}{l}\text { Production } \\
\text { costs }\end{array}$ & $\begin{array}{c}\text { Thous. 1997\$ } \\
\text { / year }\end{array}$ & $\begin{array}{c}204,087 \\
(163,180)\end{array}$ & $\begin{array}{c}1,049,567 \\
(1,013,677)\end{array}$ & $\begin{array}{c}205,750 \\
(180,301)\end{array}$ & $\begin{array}{c}515,123 \\
(674,298)\end{array}$ & $\begin{array}{c}227,022 \\
(211,919)\end{array}$ & $\begin{array}{c}1,122,095 \\
(1,154,157)\end{array}$ & $\begin{array}{c}208,478 \\
(219,856)\end{array}$ & $\begin{array}{c}558,457 \\
(722,426)\end{array}$ & $\begin{array}{c}67,408 \\
(73,005)\end{array}$ & $\begin{array}{c}97,225 \\
(98,833)\end{array}$ & $\begin{array}{c}38,693 \\
(33,525)\end{array}$ & $\begin{array}{c}43,085 \\
(86,961)\end{array}$ & $\begin{array}{c}185,658 \\
(306,156)\end{array}$ & $\begin{array}{c}64,241 \\
(70,541)\end{array}$ \\
\hline Total costs & $\begin{array}{c}\text { Thous. 1997\$ } \\
\text { / year }\end{array}$ & $\begin{array}{c}207,556 \\
(165,287)\end{array}$ & $\begin{array}{c}1,061,091 \\
(1,027,564)\end{array}$ & $\begin{array}{c}207,853 \\
(182,165)\end{array}$ & $\begin{array}{c}523,023 \\
(686,588)\end{array}$ & $\begin{array}{c}230,555 \\
(214,029)\end{array}$ & $\begin{array}{c}1,135,332 \\
(1,168,775)\end{array}$ & $\begin{array}{c}210,865 \\
(222,615)\end{array}$ & $\begin{array}{c}566,878 \\
(734,342)\end{array}$ & $\begin{array}{c}68,635 \\
(73,178)\end{array}$ & $\begin{array}{c}97,599 \\
(99,173)\end{array}$ & $\begin{array}{c}38,829 \\
(33,623)\end{array}$ & $\begin{array}{c}43,225 \\
(87,237)\end{array}$ & $\begin{array}{c}187,116 \\
(307,612)\end{array}$ & $\begin{array}{c}64,485 \\
(70,684)\end{array}$ \\
\hline $\begin{array}{l}\text { PAOC-to- } \\
\text { Prod. cost } \\
\text { ratio }\end{array}$ & $\%$ & $\begin{array}{c}1.79 \\
(1.79)\end{array}$ & $\begin{array}{c}0.88 \\
(0.95)\end{array}$ & $\begin{array}{c}1.10 \\
(1.03)\end{array}$ & $\begin{array}{c}1.22 \\
(0.89)\end{array}$ & $\begin{array}{c}1.81 \\
(4.46)\end{array}$ & $\begin{array}{c}0.95 \\
(1.06)\end{array}$ & $\begin{array}{c}1.19 \\
(1.28)\end{array}$ & $\begin{array}{c}1.28 \\
(1.04)\end{array}$ & $\begin{array}{c}2.26 \\
(2.22)\end{array}$ & $\begin{array}{c}0.40 \\
(0.72)\end{array}$ & $\begin{array}{c}0.32 \\
(0.43)\end{array}$ & $\begin{array}{c}0.37 \\
(0.52)\end{array}$ & $\begin{array}{c}0.87 \\
(1.76)\end{array}$ & $\begin{array}{c}0.48 \\
(1.16)\end{array}$ \\
\hline $\begin{array}{l}\text { PAOC share in } \\
\text { total costs }\end{array}$ & $\%$ & $\begin{array}{c}1.73 \\
(1.63)\end{array}$ & $\begin{array}{c}0.87 \\
(0.91)\end{array}$ & $\begin{array}{c}1.07 \\
(0.99)\end{array}$ & $\begin{array}{c}1.20 \\
(0.86)\end{array}$ & $\begin{array}{c}1.69 \\
(2.37)\end{array}$ & $\begin{array}{c}0.93 \\
(1.01)\end{array}$ & $\begin{array}{c}1.16 \\
(1.19)\end{array}$ & $\begin{array}{c}1.25 \\
(0.99)\end{array}$ & $\begin{array}{c}2.17 \\
(1.93)\end{array}$ & $\begin{array}{c}0.40 \\
(0.68)\end{array}$ & $\begin{array}{c}0.31 \\
(0.43)\end{array}$ & $\begin{array}{c}0.37 \\
(0.51)\end{array}$ & $\begin{array}{c}0.84 \\
(1.46)\end{array}$ & $\begin{array}{c}0.46 \\
(0.97)\end{array}$ \\
\hline $\begin{array}{l}\text { Labor cost } \\
\text { share }\end{array}$ & $\%$ & $\begin{array}{l}11.66 \\
(4.33)\end{array}$ & $\begin{array}{c}1.58 \\
(1.22)\end{array}$ & $\begin{array}{c}8.25 \\
(4.71)\end{array}$ & $\begin{array}{l}17.25 \\
(7.12)\end{array}$ & $\begin{array}{l}11.16 \\
(4.49)\end{array}$ & $\begin{array}{c}1.75 \\
(1.27)\end{array}$ & $\begin{array}{c}7.22 \\
(4.47)\end{array}$ & $\begin{array}{l}15.95 \\
(7.58)\end{array}$ & $\begin{array}{c}9.91 \\
(4.96)\end{array}$ & $\begin{array}{l}12.58 \\
(6.37)\end{array}$ & $\begin{array}{l}25.13 \\
(7.98)\end{array}$ & $\begin{array}{l}19.83 \\
(8.21)\end{array}$ & $\begin{array}{l}12.60 \\
(6.56)\end{array}$ & $\begin{array}{l}18.85 \\
(9.48)\end{array}$ \\
\hline $\begin{array}{l}\text { Capital cost } \\
\text { share }\end{array}$ & $\%$ & $\begin{array}{c}42.93 \\
(15.15)\end{array}$ & $\begin{array}{c}23.63 \\
(11.29)\end{array}$ & $\begin{array}{c}29.72 \\
(13.24)\end{array}$ & $\begin{array}{c}31.60 \\
(12.93)\end{array}$ & $\begin{array}{c}46.30 \\
(15.75)\end{array}$ & $\begin{array}{c}25.04 \\
(12.85)\end{array}$ & $\begin{array}{c}33.80 \\
(15.17)\end{array}$ & $\begin{array}{c}35.28 \\
(14.59)\end{array}$ & $\begin{array}{c}60.77 \\
(14.88)\end{array}$ & $\begin{array}{c}22.25 \\
(13.58)\end{array}$ & $\begin{array}{c}28.95 \\
(12.33)\end{array}$ & $\begin{array}{c}18.11 \\
(13.56)\end{array}$ & $\begin{array}{c}44.26 \\
(18.44)\end{array}$ & $\begin{array}{c}23.13 \\
(12.54)\end{array}$ \\
\hline $\begin{array}{l}\text { Energy cost } \\
\text { share }\end{array}$ & $\%$ & $\begin{array}{c}8.05 \\
(3.75)\end{array}$ & $\begin{array}{c}2.07 \\
(1.83)\end{array}$ & $\begin{array}{c}4.36 \\
(2.52)\end{array}$ & $\begin{array}{c}8.10 \\
(4.41)\end{array}$ & $\begin{array}{c}7.17 \\
(3.63)\end{array}$ & $\begin{array}{c}2.20 \\
(1.78)\end{array}$ & $\begin{array}{c}3.79 \\
(2.63)\end{array}$ & $\begin{array}{c}7.36 \\
(4.30)\end{array}$ & $\begin{array}{l}15.64 \\
(7.11)\end{array}$ & $\begin{array}{c}2.40 \\
(1.77)\end{array}$ & $\begin{array}{c}2.17 \\
(1.55)\end{array}$ & $\begin{array}{c}1.19 \\
(1.29)\end{array}$ & $\begin{array}{c}2.30 \\
(1.89)\end{array}$ & $\begin{array}{c}2.24 \\
(1.45)\end{array}$ \\
\hline
\end{tabular}




\section{Appendix C: Differences between Current and MPS Dataset Construction}

We started with the same Census datasets as MPS (i.e., LBD/ASM/CM data, MECS, and PACE) and tried to follow the same data construction process as much as possible, but some differences arose due to changes in data availability. The differences between our approaches are described below:

1. Output - No differences.

2. Labor - No differences.

3. Materials - Materials spending came from the cost of materials in the LRD in both MPS and our analysis. MPS derived the price of materials from the Census-year data on the cost and quantity for individual materials, allowing them to calculate a plant-specific price for each material. They then aggregated those individual materials prices into an aggregated divisia price index. This price index was linearly interpolated between the Census years. As noted earlier, Census cutbacks in collection of materials quantity data forced us to depend on BLS PPI data for specific materials.

4. Energy - MPS limited their analysis to years with plant-specific data on cost and quantity for several fuel types, either from the LRD itself (1979-1981) or the MECS data. These were used to calculate plantspecific fuel prices in each year, aggregated up to a divisia price index. After 1994 there were no years when both the energy and PACE data were collected, so we switched to an approach that interpolated energy prices between MECS years.

5. Capital - For capital input, the LRD provided annual data on new capital expenditures and some data on the (nominal) gross book value of a plant's capital stock, but these needed to be combined with other data to generate a measure of real capital stocks and capital service prices. MPS used their own perpetual inventory calculation to derive plant-specific real capital stocks. We relied on an LRD-linked database created by John Haltiwanger using a similar calculation for the real capital stock for each plant. MPS used industry-level capital service prices, taken from the KLEM sectoral input-output database for 1947-1991 (same vintage as used by MPS), developed by Dale Jorgenson and described in Jorgenson and Stiroh (2000), Jorgenson (1990), and Jorgenson, Gollop and Fraumeni (1987). Since we needed post1991 prices, we used an updated version (also from Jorgenson). In both approaches, the plant's annual capital expenditures were calculated as the product of the service price and the plant's real capital stock.

6. Regulation - No differences. 
Appendix D: Estimates of the Cost Function Coefficients

Appendix Table D1

Comparison between MPS ${ }^{a}$ and Currently Estimated Cost Function Coefficients (MPS Industries and Years ${ }^{b}$ )

\begin{tabular}{|c|c|c|c|c|c|c|c|c|}
\hline \multirow{2}{*}{$\begin{array}{l}\text { Industry: } \\
\text { Analysis: }\end{array}$} & \multicolumn{2}{|c|}{ Paper } & \multicolumn{2}{|c|}{ Petroleum } & \multicolumn{2}{|c|}{ Plastics } & \multicolumn{2}{|c|}{ Steel } \\
\hline & MPS & Current & MPS & Current & MPS & Current & MPS & Current \\
\hline Parameter $^{c}$ & \multicolumn{8}{|c|}{ Point Estimate (Standard Error in Parentheses) } \\
\hline$\alpha_{r}$ & $\begin{array}{c}-0.6221 \\
(0.2746)\end{array}$ & $\begin{array}{c}1.1914 \\
(0.4847)\end{array}$ & $\begin{array}{c}0.5900 \\
(0.5905)\end{array}$ & $\begin{array}{c}1.1814 \\
(0.8338)\end{array}$ & $\begin{array}{c}0.3774 \\
(0.6958)\end{array}$ & $\begin{array}{c}4.7784 \\
(1.0848)\end{array}$ & $\begin{array}{c}-0.0726 \\
(0.4671)\end{array}$ & $\begin{array}{c}3.2705 \\
(0.9480)\end{array}$ \\
\hline$\alpha_{y}$ & $\begin{array}{c}0.7161 \\
(0.0273)\end{array}$ & $\begin{array}{c}0.5355 \\
(0.0302)\end{array}$ & $\begin{array}{c}0.7433 \\
(0.0281)\end{array}$ & $\begin{array}{c}0.5944 \\
(0.0252)\end{array}$ & $\begin{array}{c}0.8314 \\
(0.0362)\end{array}$ & $\begin{array}{c}0.4190 \\
(0.0341)\end{array}$ & $\begin{array}{c}0.7136 \\
(0.0304)\end{array}$ & $\begin{array}{c}0.5675 \\
(0.0215)\end{array}$ \\
\hline $\boldsymbol{B}_{e e}$ & $\begin{array}{c}0.0579 \\
(0.0090)\end{array}$ & $\begin{array}{c}-0.0083 \\
(0.0037)\end{array}$ & $\begin{array}{c}0.0128 \\
(0.0018)\end{array}$ & $\begin{array}{c}-0.0014 \\
(0.0018)\end{array}$ & $\begin{array}{l}-0.0027 \\
(0.0163)\end{array}$ & $\begin{array}{c}-0.0096 \\
(0.0039)\end{array}$ & $\begin{array}{c}0.0211 \\
(0.0209)\end{array}$ & $\begin{array}{c}0.0029 \\
(0.0064)\end{array}$ \\
\hline $\boldsymbol{B}_{k k}$ & $\begin{array}{c}0.1095 \\
(0.0379)\end{array}$ & $\begin{array}{l}-0.2610 \\
(0.0460)\end{array}$ & $\begin{array}{c}0.0070 \\
(0.0019)\end{array}$ & $\begin{array}{c}0.0085 \\
(0.2174)\end{array}$ & $\begin{array}{c}0.0029 \\
(0.0190)\end{array}$ & $\begin{array}{c}0.0051 \\
(0.0639)\end{array}$ & $\begin{array}{c}0.0664 \\
(0.0172)\end{array}$ & $\begin{array}{l}-1.0383 \\
(0.4306)\end{array}$ \\
\hline $\boldsymbol{B}_{\|}$ & $\begin{array}{c}0.1120 \\
(0.0114)\end{array}$ & $\begin{array}{c}0.0633 \\
(0.0061)\end{array}$ & $\begin{array}{c}0.0133 \\
(0.0016)\end{array}$ & $\begin{array}{c}0.0060 \\
(0.0015)\end{array}$ & $\begin{array}{c}0.0668 \\
(0.0094)\end{array}$ & $\begin{array}{c}0.0410 \\
(0.0075)\end{array}$ & $\begin{array}{c}0.0491 \\
(0.0201)\end{array}$ & $\begin{array}{c}0.0835 \\
(0.0215)\end{array}$ \\
\hline $\boldsymbol{B}_{k e}$ & $\begin{array}{l}-0.0116 \\
(0.0112)\end{array}$ & $\begin{array}{c}-0.0012 \\
(0.0084)\end{array}$ & $\begin{array}{c}0.0005 \\
(0.0012)\end{array}$ & $\begin{array}{c}-0.0028 \\
(0.0071)\end{array}$ & $\begin{array}{c}0.0103 \\
(0.0086)\end{array}$ & $\begin{array}{c}0.0052 \\
(0.0100)\end{array}$ & $\begin{array}{l}-0.0264 \\
(0.0073)\end{array}$ & $\begin{array}{c}0.0273 \\
(0.0099)\end{array}$ \\
\hline $\boldsymbol{B}_{l e}$ & $\begin{array}{c}-0.0114 \\
(0.0065)\end{array}$ & $\begin{array}{l}-0.0026 \\
(0.0026)\end{array}$ & $\begin{array}{c}0.0003 \\
(0.0010)\end{array}$ & $\begin{array}{c}0.0005 \\
(0.0007)\end{array}$ & $\begin{array}{l}-0.0016 \\
(0.0068)\end{array}$ & $\begin{array}{l}-0.0019 \\
(0.0038)\end{array}$ & $\begin{array}{c}0.0156 \\
(0.0138)\end{array}$ & $\begin{array}{c}-0.0131 \\
(0.0073)\end{array}$ \\
\hline $\boldsymbol{B}_{k l}$ & $\begin{array}{c}-0.0347 \\
(0.0128)\end{array}$ & $\begin{array}{c}0.0009 \\
(0.0110)\end{array}$ & $\begin{array}{c}0.0017 \\
(0.0008)\end{array}$ & $\begin{array}{c}0.0411 \\
(0.0117)\end{array}$ & $\begin{array}{l}-0.0030 \\
(0.0092)\end{array}$ & $\begin{array}{c}0.0106 \\
(0.0152)\end{array}$ & $\begin{array}{l}-0.0035 \\
(0.0088)\end{array}$ & $\begin{array}{c}0.0194 \\
(0.0217)\end{array}$ \\
\hline $\boldsymbol{B}_{e y}$ & $\begin{array}{l}-0.0041 \\
(0.0053)\end{array}$ & $\begin{array}{c}0.0062 \\
(0.0037)\end{array}$ & $\begin{array}{l}-0.0104 \\
(0.0015)\end{array}$ & $\begin{array}{c}-0.0024 \\
(0.0017)\end{array}$ & $\begin{array}{c}0.0085 \\
(0.0092)\end{array}$ & $\begin{array}{l}-0.0055 \\
(0.0020)\end{array}$ & $\begin{array}{l}-0.0177 \\
(0.0087)\end{array}$ & $\begin{array}{c}0.0124 \\
(0.0034)\end{array}$ \\
\hline $\boldsymbol{B}_{k y}$ & $\begin{array}{c}0.0100 \\
(0.0071)\end{array}$ & $\begin{array}{l}-0.0550 \\
(0.0114)\end{array}$ & $\begin{array}{c}-0.0132 \\
(0.0021)\end{array}$ & $\begin{array}{l}-0.1019 \\
(0.0087)\end{array}$ & $\begin{array}{l}-0.0365 \\
(0.0049)\end{array}$ & $\begin{array}{l}-0.0863 \\
(0.0088)\end{array}$ & $\begin{array}{l}-0.0383 \\
(0.0031)\end{array}$ & $\begin{array}{c}-0.1446 \\
(0.0053)\end{array}$ \\
\hline$B_{l y}$ & $\begin{array}{l}-0.0446 \\
(0.0052)\end{array}$ & $\begin{array}{c}-0.0154 \\
(0.0032)\end{array}$ & $\begin{array}{c}-0.0078 \\
(0.0010)\end{array}$ & $\begin{array}{c}-0.0052 \\
(0.0007)\end{array}$ & $\begin{array}{c}-0.0302 \\
(0.0041)\end{array}$ & $\begin{array}{c}-0.0034 \\
(0.0027)\end{array}$ & $\begin{array}{c}0.0066 \\
(0.0072)\end{array}$ & $\begin{array}{c}0.0234 \\
(0.0049)\end{array}$ \\
\hline $\boldsymbol{B}_{y t}$ & $\begin{array}{c}0.0041 \\
(0.0014)\end{array}$ & $\begin{array}{c}0.0027 \\
(0.0013)\end{array}$ & $\begin{array}{l}-0.0028 \\
(0.0013)\end{array}$ & $\begin{array}{c}-0.0021 \\
(0.0009)\end{array}$ & $\begin{array}{c}0.0110 \\
(0.0020)\end{array}$ & $\begin{array}{c}0.0032 \\
(0.0017)\end{array}$ & $\begin{array}{c}-0.0004 \\
(0.0014)\end{array}$ & $\begin{array}{c}-0.0017 \\
(0.0014)\end{array}$ \\
\hline $\boldsymbol{B}_{y}$ & $\begin{array}{l}-0.0336 \\
(0.0316)\end{array}$ & $\begin{array}{l}-0.1090 \\
(0.0243)\end{array}$ & $\begin{array}{c}0.0039 \\
(0.0184)\end{array}$ & $\begin{array}{l}-0.0160 \\
(0.0097)\end{array}$ & $\begin{array}{l}-0.0408 \\
(0.0328)\end{array}$ & $\begin{array}{c}-0.1742 \\
(0.0303)\end{array}$ & $\begin{array}{c}0.0389 \\
(0.0191)\end{array}$ & $\begin{array}{c}-0.0110 \\
(0.0147)\end{array}$ \\
\hline$V_{e}$ & $\begin{array}{c}0.1967 \\
(0.0846)\end{array}$ & $\begin{array}{c}0.0102 \\
(0.0772)\end{array}$ & $\begin{array}{l}-0.0225 \\
(0.0387)\end{array}$ & $\begin{array}{l}-0.1019 \\
(0.0696)\end{array}$ & $\begin{array}{c}0.2930 \\
(0.2028)\end{array}$ & $\begin{array}{c}0.4974 \\
(0.0845)\end{array}$ & $\begin{array}{l}-0.7126 \\
(0.1952)\end{array}$ & $\begin{array}{c}0.0618 \\
(0.1981)\end{array}$ \\
\hline$\gamma_{k}$ & $\begin{array}{c}0.1276 \\
(0.1085)\end{array}$ & $\begin{array}{c}0.7920 \\
(0.2311)\end{array}$ & $\begin{array}{c}0.0532 \\
(0.0545)\end{array}$ & $\begin{array}{c}0.9472 \\
(0.3456)\end{array}$ & $\begin{array}{l}-0.0510 \\
(0.1053)\end{array}$ & $\begin{array}{c}0.7190 \\
(0.3553)\end{array}$ & $\begin{array}{c}0.1460 \\
(0.0715)\end{array}$ & $\begin{array}{c}-0.8591 \\
(0.3078)\end{array}$ \\
\hline$v_{I}$ & $\begin{array}{c}0.1531 \\
(0.0770)\end{array}$ & $\begin{array}{c}0.1564 \\
(0.0651)\end{array}$ & $\begin{array}{c}0.0748 \\
(0.0292)\end{array}$ & $\begin{array}{c}0.0371 \\
(0.0300)\end{array}$ & $\begin{array}{c}0.3621 \\
(0.0914)\end{array}$ & $\begin{array}{c}0.4326 \\
(0.1100)\end{array}$ & $\begin{array}{c}0.1565 \\
(0.1610)\end{array}$ & $\begin{array}{c}0.3914 \\
(0.2828)\end{array}$ \\
\hline$\delta_{e e}$ & $\begin{array}{c}0.4141 \\
(0.1679)\end{array}$ & $\begin{array}{c}0.6028 \\
(0.1333)\end{array}$ & $\begin{array}{l}-0.1483 \\
(0.0690)\end{array}$ & $\begin{array}{c}0.2817 \\
(0.1077)\end{array}$ & $\begin{array}{l}-0.3730 \\
(0.5119)\end{array}$ & $\begin{array}{c}0.6348 \\
(0.2972)\end{array}$ & $\begin{array}{l}-0.1428 \\
(0.5534)\end{array}$ & $\begin{array}{c}-0.5693 \\
(0.2428)\end{array}$ \\
\hline$\delta_{k k}$ & $\begin{array}{c}0.9811 \\
(0.4718)\end{array}$ & $\begin{array}{c}2.0289 \\
(0.7747)\end{array}$ & $\begin{array}{c}0.3400 \\
(0.0964)\end{array}$ & $\begin{array}{c}0.2085 \\
(0.6933)\end{array}$ & $\begin{array}{c}0.4311 \\
(0.4545)\end{array}$ & $\begin{array}{c}1.5856 \\
(1.2929)\end{array}$ & $\begin{array}{c}0.5153 \\
(0.2243)\end{array}$ & $\begin{array}{c}-2.1443 \\
(1.7474)\end{array}$ \\
\hline$\delta_{\|}$ & $\begin{array}{c}-0.3011 \\
(0.3037)\end{array}$ & $\begin{array}{c}-0.0454 \\
(0.2165)\end{array}$ & $\begin{array}{c}-0.2801 \\
(0.0986)\end{array}$ & $\begin{array}{c}-0.3105 \\
(0.1111)\end{array}$ & $\begin{array}{l}-1.1840 \\
(0.3458)\end{array}$ & $\begin{array}{c}0.0236 \\
(0.3391)\end{array}$ & $\begin{array}{c}1.4959 \\
(0.5676)\end{array}$ & $\begin{array}{c}1.1337 \\
(1.2513)\end{array}$ \\
\hline$\delta_{k e}$ & $\begin{array}{l}-0.1040 \\
(0.1996)\end{array}$ & $\begin{array}{l}-0.1923 \\
(0.2321)\end{array}$ & $\begin{array}{c}0.1260 \\
(0.0554)\end{array}$ & $\begin{array}{l}-0.1519 \\
(0.1399)\end{array}$ & $\begin{array}{c}0.1902 \\
(0.2624)\end{array}$ & $\begin{array}{l}-1.2811 \\
(0.3223)\end{array}$ & $\begin{array}{c}0.4567 \\
(0.1942)\end{array}$ & $\begin{array}{l}-0.9256 \\
(0.3668)\end{array}$ \\
\hline$\delta_{l e}$ & $\begin{array}{c}-0.2485 \\
(0.1375)\end{array}$ & $\begin{array}{c}-0.1664 \\
(0.0951)\end{array}$ & $\begin{array}{c}0.0026 \\
(0.0398)\end{array}$ & $\begin{array}{l}-0.0096 \\
(0.0421)\end{array}$ & $\begin{array}{c}0.1503 \\
(0.2211)\end{array}$ & $\begin{array}{c}0.1565 \\
(0.2213)\end{array}$ & $\begin{array}{c}-0.8998 \\
(0.3833)\end{array}$ & $\begin{array}{c}0.2076 \\
(0.3067)\end{array}$ \\
\hline$\delta_{k l}$ & $\begin{array}{l}-0.0764 \\
(0.2554)\end{array}$ & $\begin{array}{l}-0.0822 \\
(0.2177)\end{array}$ & $\begin{array}{c}0.0078 \\
(0.0394)\end{array}$ & $\begin{array}{c}0.0918 \\
(0.0776)\end{array}$ & $\begin{array}{c}0.0251 \\
(0.2843)\end{array}$ & $\begin{array}{c}0.0717 \\
(0.4044)\end{array}$ & $\begin{array}{l}-0.1398 \\
(0.2375)\end{array}$ & $\begin{array}{l}-3.6834 \\
(1.0493)\end{array}$ \\
\hline$\delta_{\text {et }}$ & $\begin{array}{c}-0.0232 \\
(0.0107)\end{array}$ & $\begin{array}{c}-0.0203 \\
(0.0108)\end{array}$ & $\begin{array}{l}-0.0115 \\
(0.0076)\end{array}$ & $\begin{array}{l}-0.0135 \\
(0.0138)\end{array}$ & $\begin{array}{l}-0.0426 \\
(0.0290)\end{array}$ & $\begin{array}{l}-0.0258 \\
(0.0163)\end{array}$ & $\begin{array}{c}0.0501 \\
(0.0346)\end{array}$ & $\begin{array}{c}-0.0723 \\
(0.0332)\end{array}$ \\
\hline$\delta_{k t}$ & $\begin{array}{c}0.0013 \\
(0.0171)\end{array}$ & $\begin{array}{c}-0.0541 \\
(0.0295)\end{array}$ & $\begin{array}{c}-0.0043 \\
(0.0110)\end{array}$ & $\begin{array}{c}0.0419 \\
(0.0554)\end{array}$ & $\begin{array}{c}0.0627 \\
(0.0186)\end{array}$ & $\begin{array}{c}-0.0358 \\
(0.0709)\end{array}$ & $\begin{array}{c}-0.0122 \\
(0.0160)\end{array}$ & $\begin{array}{c}0.2428 \\
(0.0713)\end{array}$ \\
\hline$\delta_{l t}$ & $\begin{array}{c}-0.0154 \\
(0.0126)\end{array}$ & $\begin{array}{c}-0.0082 \\
(0.0093)\end{array}$ & $\begin{array}{c}0.0097 \\
(0.0067)\end{array}$ & $\begin{array}{c}0.0207 \\
(0.0082)\end{array}$ & $\begin{array}{c}0.0516 \\
(0.0181)\end{array}$ & $\begin{array}{l}-0.0312 \\
(0.0213)\end{array}$ & $\begin{array}{l}-0.0935 \\
(0.0355)\end{array}$ & $\begin{array}{c}0.0381 \\
(0.0585)\end{array}$ \\
\hline
\end{tabular}

Notes: (a) We derived MPS estimates from MPS Table V, pp. 432-433. (b) The years included are: 1979, 1980, 1981, $1985,1988,1991$. (c) We could not disclose time and plant dummies. 
Appendix Table D2

Estimated Cost Function Coefficients for 10 Industries (using all available years ${ }^{\mathrm{a}}$ )

\begin{tabular}{|c|c|c|c|c|c|c|c|c|c|c|}
\hline Industry: & Paper & Petroleum & Plastics & Steel & $\begin{array}{c}\text { Portland } \\
\text { Cement }\end{array}$ & $\begin{array}{l}\text { Rolling and } \\
\text { Drawing }\end{array}$ & Pipe Fitting & $\begin{array}{l}\text { Misc. } \\
\text { Wood } \\
\text { Products }\end{array}$ & $\begin{array}{l}\text { Pharmaceu } \\
\text {-ticals }\end{array}$ & $\begin{array}{c}\text { Other } \\
\text { Electrical } \\
\text { Equipment }\end{array}$ \\
\hline Parameter $^{b}$ & \multicolumn{10}{|c|}{ Point Estimate (Standard Error in Parentheses) } \\
\hline$\alpha_{r}$ & $\begin{array}{l}-0.6136 \\
(0.1678)\end{array}$ & $\begin{array}{c}3.3653 \\
(0.5269)\end{array}$ & $\begin{array}{c}2.7525 \\
(0.4992)\end{array}$ & $\begin{array}{c}3.5439 \\
(0.5723)\end{array}$ & $\begin{array}{c}1.5405 \\
(0.6325)\end{array}$ & $\begin{array}{c}3.1672 \\
(0.9613)\end{array}$ & $\begin{array}{c}4.6354 \\
(2.3346)\end{array}$ & $\begin{array}{c}2.2143 \\
(1.5843)\end{array}$ & $\begin{array}{c}0.6368 \\
(0.6356)\end{array}$ & $\begin{array}{l}-1.6668 \\
(0.7265)\end{array}$ \\
\hline $\boldsymbol{\alpha}_{y}$ & $\begin{array}{c}0.5397 \\
(0.0157)\end{array}$ & $\begin{array}{c}0.5609 \\
(0.0166)\end{array}$ & $\begin{array}{c}0.4512 \\
(0.0152)\end{array}$ & $\begin{array}{c}0.5235 \\
(0.0143)\end{array}$ & $\begin{array}{c}0.3031 \\
(0.0377)\end{array}$ & $\begin{array}{c}0.6826 \\
(0.0152)\end{array}$ & $\begin{array}{c}0.3159 \\
(0.0189)\end{array}$ & $\begin{array}{c}0.6822 \\
(0.0201)\end{array}$ & $\begin{array}{c}0.2663 \\
(0.0171)\end{array}$ & $\begin{array}{c}0.4819 \\
(0.0143)\end{array}$ \\
\hline $\boldsymbol{B}_{e e}$ & $\begin{array}{c}-0.0021 \\
(0.0018)\end{array}$ & $\begin{array}{c}-0.0001 \\
(0.0010)\end{array}$ & $\begin{array}{c}-0.0070 \\
(0.0017)\end{array}$ & $\begin{array}{c}0.0009 \\
(0.0037)\end{array}$ & $\begin{array}{c}-0.0506 \\
(0.0079)\end{array}$ & $\begin{array}{c}0.0059 \\
(0.0022)\end{array}$ & $\begin{array}{c}0.0055 \\
(0.0017)\end{array}$ & $\begin{array}{c}-0.0009 \\
(0.0008)\end{array}$ & $\begin{array}{c}-0.0012 \\
(0.0015)\end{array}$ & $\begin{array}{c}0.0059 \\
(0.0017)\end{array}$ \\
\hline $\boldsymbol{B}_{k k}$ & $\begin{array}{c}-0.2560 \\
(0.0276)\end{array}$ & $\begin{array}{c}-0.1421 \\
(0.1218)\end{array}$ & $\begin{array}{c}0.0893 \\
(0.0332)\end{array}$ & $\begin{array}{c}-0.7138 \\
(0.2260)\end{array}$ & $\begin{array}{c}-0.3185 \\
(0.1494)\end{array}$ & $\begin{array}{c}0.1451 \\
(0.0294)\end{array}$ & $\begin{array}{c}0.0951 \\
(0.0691)\end{array}$ & $\begin{array}{c}0.0999 \\
(0.0564)\end{array}$ & $\begin{array}{c}0.1205 \\
(0.0607)\end{array}$ & $\begin{array}{c}0.1637 \\
(0.0352)\end{array}$ \\
\hline $\boldsymbol{B}_{\|}$ & $\begin{array}{c}0.0487 \\
(0.0031)\end{array}$ & $\begin{array}{c}0.0083 \\
(0.0008)\end{array}$ & $\begin{array}{c}0.0365 \\
(0.0028)\end{array}$ & $\begin{array}{c}0.0401 \\
(0.0083)\end{array}$ & $\begin{array}{c}0.0535 \\
(0.0061)\end{array}$ & $\begin{array}{c}0.0401 \\
(0.0055)\end{array}$ & $\begin{array}{c}0.0880 \\
(0.0116)\end{array}$ & $\begin{array}{c}0.0599 \\
(0.0080)\end{array}$ & $\begin{array}{c}0.0577 \\
(0.0046)\end{array}$ & $\begin{array}{c}0.0638 \\
(0.0073)\end{array}$ \\
\hline $\boldsymbol{B}_{k e}$ & $\begin{array}{c}0.0103 \\
(0.0048)\end{array}$ & $\begin{array}{c}0.0021 \\
(0.0049)\end{array}$ & $\begin{array}{c}-0.0053 \\
(0.0048)\end{array}$ & $\begin{array}{c}0.0002 \\
(0.0076)\end{array}$ & $\begin{array}{c}0.0499 \\
(0.0136)\end{array}$ & $\begin{array}{c}0.0109 \\
(0.0053)\end{array}$ & $\begin{array}{c}0.0146 \\
(0.0058)\end{array}$ & $\begin{array}{c}0.0045 \\
(0.0038)\end{array}$ & $\begin{array}{l}-0.0014 \\
(0.0060)\end{array}$ & $\begin{array}{c}0.0140 \\
(0.0050)\end{array}$ \\
\hline $\boldsymbol{B}_{l e}$ & $\begin{array}{c}-0.0041 \\
(0.0015)\end{array}$ & $\begin{array}{c}0.0000 \\
(0.0004)\end{array}$ & $\begin{array}{c}-0.0026 \\
(0.0016)\end{array}$ & $\begin{array}{c}-0.0152 \\
(0.0038)\end{array}$ & $\begin{array}{c}-0.0257 \\
(0.0046)\end{array}$ & $\begin{array}{c}-0.0028 \\
(0.0021)\end{array}$ & $\begin{array}{c}-0.0042 \\
(0.0015)\end{array}$ & $\begin{array}{c}0.0004 \\
(0.0009)\end{array}$ & $\begin{array}{c}-0.0018 \\
(0.0013)\end{array}$ & $\begin{array}{l}-0.0035 \\
(0.0017)\end{array}$ \\
\hline $\boldsymbol{B}_{k l}$ & $\begin{array}{c}-0.0049 \\
(0.0068)\end{array}$ & $\begin{array}{c}0.0176 \\
(0.0067)\end{array}$ & $\begin{array}{c}-0.0168 \\
(0.0060)\end{array}$ & $\begin{array}{c}-0.0128 \\
(0.0125)\end{array}$ & $\begin{array}{c}0.0136 \\
(0.0142)\end{array}$ & $\begin{array}{c}0.0029 \\
(0.0093)\end{array}$ & $\begin{array}{l}-0.0133 \\
(0.0153)\end{array}$ & $\begin{array}{c}-0.0009 \\
(0.0120)\end{array}$ & $\begin{array}{l}-0.0183 \\
(0.0108)\end{array}$ & $\begin{array}{l}-0.0341 \\
(0.0105)\end{array}$ \\
\hline $\boldsymbol{B}_{e y}$ & $\begin{array}{c}0.0018 \\
(0.0015)\end{array}$ & $\begin{array}{l}-0.0014 \\
(0.0010)\end{array}$ & $\begin{array}{c}-0.0021 \\
(0.0008)\end{array}$ & $\begin{array}{c}0.0103 \\
(0.0016)\end{array}$ & $\begin{array}{c}0.0368 \\
(0.0044)\end{array}$ & $\begin{array}{c}-0.0044 \\
(0.0008)\end{array}$ & $\begin{array}{l}-0.0027 \\
(0.0005)\end{array}$ & $\begin{array}{c}-0.0018 \\
(0.0003)\end{array}$ & $\begin{array}{l}-0.0022 \\
(0.0005)\end{array}$ & $\begin{array}{l}-0.0019 \\
(0.0006)\end{array}$ \\
\hline $\boldsymbol{B}_{k y}$ & $\begin{array}{l}-0.0396 \\
(0.0054)\end{array}$ & $\begin{array}{l}-0.0861 \\
(0.0058)\end{array}$ & $\begin{array}{c}-0.0885 \\
(0.0039)\end{array}$ & $\begin{array}{c}-0.1177 \\
(0.0035)\end{array}$ & $\begin{array}{c}-0.0989 \\
(0.0092)\end{array}$ & $\begin{array}{l}-0.1058 \\
(0.0043)\end{array}$ & $\begin{array}{l}-0.0515 \\
(0.0057)\end{array}$ & $\begin{array}{c}-0.0947 \\
(0.0048)\end{array}$ & $\begin{array}{l}-0.0594 \\
(0.0042)\end{array}$ & $\begin{array}{l}-0.0619 \\
(0.0036)\end{array}$ \\
\hline $\boldsymbol{B}_{l y}$ & $\begin{array}{c}-0.0052 \\
(0.0016)\end{array}$ & $\begin{array}{l}-0.0046 \\
(0.0005)\end{array}$ & $\begin{array}{c}-0.0008 \\
(0.0010)\end{array}$ & $\begin{array}{c}0.0164 \\
(0.0022)\end{array}$ & $\begin{array}{c}0.0084 \\
(0.0030)\end{array}$ & $\begin{array}{c}-0.0021 \\
(0.0020)\end{array}$ & $\begin{array}{c}0.0008 \\
(0.0039)\end{array}$ & $\begin{array}{c}0.0027 \\
(0.0031)\end{array}$ & $\begin{array}{l}-0.0002 \\
(0.0016)\end{array}$ & $\begin{array}{l}-0.0016 \\
(0.0024)\end{array}$ \\
\hline $\boldsymbol{B}_{y t}$ & $\begin{array}{c}0.0026 \\
(0.0006)\end{array}$ & $\begin{array}{l}-0.0016 \\
(0.0005)\end{array}$ & $\begin{array}{c}0.0006 \\
(0.0007)\end{array}$ & $\begin{array}{c}-0.0024 \\
(0.0007)\end{array}$ & $\begin{array}{c}-0.0174 \\
(0.0028)\end{array}$ & $\begin{array}{c}-0.0028 \\
(0.0009)\end{array}$ & $\begin{array}{c}-0.0037 \\
(0.0011)\end{array}$ & $\begin{array}{c}0.0005 \\
(0.0009)\end{array}$ & $\begin{array}{c}0.0046 \\
(0.0009)\end{array}$ & $\begin{array}{l}-0.0021 \\
(0.0008)\end{array}$ \\
\hline $\boldsymbol{B}_{y}$ & $\begin{array}{c}0.0023 \\
(0.0083)\end{array}$ & $\begin{array}{l}-0.0152 \\
(0.0057)\end{array}$ & $\begin{array}{c}0.0160 \\
(0.0090)\end{array}$ & $\begin{array}{c}0.0469 \\
(0.0063)\end{array}$ & $\begin{array}{c}-0.2097 \\
(0.0481)\end{array}$ & $\begin{array}{c}0.0087 \\
(0.0107)\end{array}$ & $\begin{array}{l}-0.0422 \\
(0.0102)\end{array}$ & $\begin{array}{c}-0.0012 \\
(0.0109)\end{array}$ & $\begin{array}{l}-0.0533 \\
(0.0120)\end{array}$ & $\begin{array}{c}0.0311 \\
(0.0115)\end{array}$ \\
\hline$Y e$ & $\begin{array}{c}0.1829 \\
(0.0289)\end{array}$ & $\begin{array}{c}0.0149 \\
(0.0363)\end{array}$ & $\begin{array}{c}0.2222 \\
(0.0363)\end{array}$ & $\begin{array}{c}0.1056 \\
(0.1054)\end{array}$ & $\begin{array}{c}0.3672 \\
(0.1005)\end{array}$ & $\begin{array}{c}0.1268 \\
(0.0700)\end{array}$ & $\begin{array}{c}0.1432 \\
(0.0757)\end{array}$ & $\begin{array}{c}-0.0962 \\
(0.0544)\end{array}$ & $\begin{array}{c}0.2086 \\
(0.0402)\end{array}$ & $\begin{array}{c}0.1021 \\
(0.0509)\end{array}$ \\
\hline$V_{k}$ & $\begin{array}{c}0.3194 \\
(0.0938)\end{array}$ & $\begin{array}{c}1.5044 \\
(0.2159)\end{array}$ & $\begin{array}{c}0.7258 \\
(0.1881)\end{array}$ & $\begin{array}{c}0.3372 \\
(0.2384)\end{array}$ & $\begin{array}{c}0.2946 \\
(0.1979)\end{array}$ & $\begin{array}{c}0.8218 \\
(0.3616)\end{array}$ & $\begin{array}{c}0.8822 \\
(0.7904)\end{array}$ & $\begin{array}{c}0.7295 \\
(0.7831)\end{array}$ & $\begin{array}{c}0.9830 \\
(0.3030)\end{array}$ & $\begin{array}{c}0.5352 \\
(0.3059)\end{array}$ \\
\hline $\boldsymbol{V} \boldsymbol{I}$ & $\begin{array}{c}0.1944 \\
(0.0297)\end{array}$ & $\begin{array}{c}0.0519 \\
(0.0175)\end{array}$ & $\begin{array}{c}0.2367 \\
(0.0482)\end{array}$ & $\begin{array}{c}0.7044 \\
(0.1459)\end{array}$ & $\begin{array}{c}0.3089 \\
(0.0692)\end{array}$ & $\begin{array}{c}0.5286 \\
(0.1653)\end{array}$ & $\begin{array}{c}0.1994 \\
(0.5614)\end{array}$ & $\begin{array}{c}0.2142 \\
(0.4891)\end{array}$ & $\begin{array}{c}0.3048 \\
(0.1243)\end{array}$ & $\begin{array}{c}0.5465 \\
(0.2095)\end{array}$ \\
\hline$\delta_{e e}$ & $\begin{array}{c}0.2657 \\
(0.0589)\end{array}$ & $\begin{array}{c}0.0735 \\
(0.0531)\end{array}$ & $\begin{array}{c}0.2855 \\
(0.1007)\end{array}$ & $\begin{array}{c}-0.4400 \\
(0.1325)\end{array}$ & $\begin{array}{c}0.3926 \\
(0.1884)\end{array}$ & $\begin{array}{c}0.1517 \\
(0.1776)\end{array}$ & $\begin{array}{l}-0.0733 \\
(0.1936)\end{array}$ & $\begin{array}{c}0.9780 \\
(0.1568)\end{array}$ & $\begin{array}{l}-0.1574 \\
(0.0721)\end{array}$ & $\begin{array}{c}0.1375 \\
(0.0972)\end{array}$ \\
\hline$\delta_{k k}$ & $\begin{array}{c}0.2239 \\
(0.4621)\end{array}$ & $\begin{array}{c}1.2674 \\
(0.3927)\end{array}$ & $\begin{array}{c}0.3395 \\
(0.6820)\end{array}$ & $\begin{array}{c}3.3141 \\
(0.7470)\end{array}$ & $\begin{array}{c}1.7878 \\
(0.5604)\end{array}$ & $\begin{array}{c}1.8314 \\
(1.9302)\end{array}$ & $\begin{array}{c}5.7744 \\
(3.6306)\end{array}$ & $\begin{array}{c}2.5047 \\
(2.4042)\end{array}$ & $\begin{array}{c}0.6905 \\
(1.2071)\end{array}$ & $\begin{array}{l}-2.3857 \\
(1.3553)\end{array}$ \\
\hline$\delta_{\|}$ & $\begin{array}{c}0.2452 \\
(0.0555)\end{array}$ & $\begin{array}{l}-0.1131 \\
(0.0435)\end{array}$ & $\begin{array}{c}-0.3605 \\
(0.0864)\end{array}$ & $\begin{array}{c}1.5972 \\
(0.4070)\end{array}$ & $\begin{array}{c}0.1248 \\
(0.1896)\end{array}$ & $\begin{array}{c}2.3706 \\
(0.4835)\end{array}$ & $\begin{array}{c}2.2388 \\
(2.0431)\end{array}$ & $\begin{array}{c}0.1637 \\
(0.9073)\end{array}$ & $\begin{array}{c}0.5635 \\
(0.2396)\end{array}$ & $\begin{array}{c}0.1086 \\
(0.4925)\end{array}$ \\
\hline$\delta_{k e}$ & $\begin{array}{c}-0.0420 \\
(0.1185)\end{array}$ & $\begin{array}{c}-0.1424 \\
(0.0636)\end{array}$ & $\begin{array}{c}-0.4973 \\
(0.1252)\end{array}$ & $\begin{array}{c}-0.1726 \\
(0.2231)\end{array}$ & $\begin{array}{c}-0.3827 \\
(0.2394)\end{array}$ & $\begin{array}{c}-0.5113 \\
(0.3271)\end{array}$ & $\begin{array}{c}-0.8661 \\
(0.3152)\end{array}$ & $\begin{array}{c}-0.2312 \\
(0.1856)\end{array}$ & $\begin{array}{c}-0.5034 \\
(0.1332)\end{array}$ & $\begin{array}{l}-0.2806 \\
(0.2069)\end{array}$ \\
\hline$\delta_{l e}$ & $\begin{array}{c}-0.0631 \\
(0.0419)\end{array}$ & $\begin{array}{l}-0.0237 \\
(0.0234)\end{array}$ & $\begin{array}{c}0.0265 \\
(0.0581)\end{array}$ & $\begin{array}{c}0.3017 \\
(0.1526)\end{array}$ & $\begin{array}{c}0.0880 \\
(0.1123)\end{array}$ & $\begin{array}{c}0.3655 \\
(0.2162)\end{array}$ & $\begin{array}{c}-0.4817 \\
(0.2566)\end{array}$ & $\begin{array}{c}-0.0824 \\
(0.1001)\end{array}$ & $\begin{array}{c}0.4039 \\
(0.0717)\end{array}$ & $\begin{array}{c}0.1248 \\
(0.1215)\end{array}$ \\
\hline$\delta_{k l}$ & $\begin{array}{c}0.0146 \\
(0.1184)\end{array}$ & $\begin{array}{l}-0.0061 \\
(0.0328)\end{array}$ & $\begin{array}{c}0.1966 \\
(0.1541)\end{array}$ & $\begin{array}{c}-0.1681 \\
(0.3707)\end{array}$ & $\begin{array}{l}-0.4937 \\
(0.1825)\end{array}$ & $\begin{array}{c}-0.4784 \\
(0.6649)\end{array}$ & $\begin{array}{l}-4.2189 \\
(1.9225)\end{array}$ & $\begin{array}{c}1.1246 \\
(1.0459)\end{array}$ & $\begin{array}{c}0.2312 \\
(0.3701)\end{array}$ & $\begin{array}{c}1.0419 \\
(0.5902)\end{array}$ \\
\hline$\delta_{\text {et }}$ & $\begin{array}{c}-0.0088 \\
(0.0037)\end{array}$ & $\begin{array}{c}0.0020 \\
(0.0042)\end{array}$ & $\begin{array}{c}-0.0038 \\
(0.0046)\end{array}$ & $\begin{array}{c}-0.0402 \\
(0.0138)\end{array}$ & $\begin{array}{l}-0.0253 \\
(0.0098)\end{array}$ & $\begin{array}{c}-0.0172 \\
(0.0135)\end{array}$ & $\begin{array}{l}-0.0102 \\
(0.0076)\end{array}$ & $\begin{array}{c}0.0105 \\
(0.0058)\end{array}$ & $\begin{array}{l}-0.0582 \\
(0.0053)\end{array}$ & $\begin{array}{l}-0.0106 \\
(0.0093)\end{array}$ \\
\hline$\delta_{k t}$ & $\begin{array}{c}-0.0178 \\
(0.0118)\end{array}$ & $\begin{array}{c}0.0506 \\
(0.0248)\end{array}$ & $\begin{array}{c}0.0325 \\
(0.0237)\end{array}$ & $\begin{array}{c}0.0528 \\
(0.0354)\end{array}$ & $\begin{array}{c}0.0341 \\
(0.0192)\end{array}$ & $\begin{array}{c}0.0893 \\
(0.0711)\end{array}$ & $\begin{array}{c}-0.3364 \\
(0.0846)\end{array}$ & $\begin{array}{c}0.0411 \\
(0.0771)\end{array}$ & $\begin{array}{c}0.0300 \\
(0.0413)\end{array}$ & $\begin{array}{l}-0.1267 \\
(0.0548)\end{array}$ \\
\hline$\delta_{l t}$ & $\begin{array}{c}-0.0084 \\
(0.0037)\end{array}$ & $\begin{array}{c}0.0042 \\
(0.0024)\end{array}$ & $\begin{array}{c}0.0140 \\
(0.0061)\end{array}$ & $\begin{array}{c}-0.0436 \\
(0.0217)\end{array}$ & $\begin{array}{c}-0.0304 \\
(0.0066)\end{array}$ & $\begin{array}{l}-0.0728 \\
(0.0306)\end{array}$ & $\begin{array}{c}0.0560 \\
(0.0584)\end{array}$ & $\begin{array}{c}-0.0061 \\
(0.0480)\end{array}$ & $\begin{array}{l}-0.0887 \\
(0.0161)\end{array}$ & $\begin{array}{l}-0.0077 \\
(0.0372)\end{array}$ \\
\hline
\end{tabular}

Notes: (a) The years included are: 1976-1982, 1984-1986, 1988-1994, 1999, and 2005. (b) We could not disclose time and plant dummies. 
FIGURES AND TABLES

Table 1

Industries in the Study

\begin{tabular}{|c|c|}
\hline Industry Name & NAICS code \\
\hline \multicolumn{2}{|r|}{ Original Industries } \\
\hline 1. Paper Mills & $322110,322121,322130$ \\
\hline 2. Petroleum Refineries & 324110 \\
\hline 3. Plastics & 3252 \\
\hline 4. Iron and Steel Mills & 331111 \\
\hline \multicolumn{2}{|r|}{ Additional Industries } \\
\hline 5. Portland Cement & 327310 \\
\hline 6. Rolling and Drawing & $331421 ; 331422 ; 331491$ \\
\hline 7. Pipe Fitting & $332911 ; 332912 ; 332919$ \\
\hline 8. Misc. Wood Products & 321911, 321912, 321918, 321920, 321991, 321992, 321999 \\
\hline 9. Pharmaceuticals & 3254 \\
\hline 10. Other Electrical Equipment & 3359 \\
\hline
\end{tabular}


Table 2

\begin{tabular}{|c|c|c|c|c|}
\hline \multicolumn{5}{|c|}{ Elasticity Estimates for MPS Industries } \\
\hline \multirow{3}{*}{ Specification } & (1) & (2) & (3) & (4) \\
\hline & Levels & First differences & $\begin{array}{c}\text { Instrument using } \\
\text { TFP, first } \\
\text { differences }\end{array}$ & $\begin{array}{c}\text { Instrument using } \\
\text { input prices, first } \\
\text { differences }\end{array}$ \\
\hline & \multicolumn{4}{|c|}{ Panel A: Paper (SIC 2611, 2621) } \\
\hline $\begin{array}{l}\text { Log output } \\
\text { price }\end{array}$ & $\begin{array}{r}-0.290 \\
(0.136)\end{array}$ & $\begin{array}{r}-0.456 \\
(0.192)\end{array}$ & $\begin{array}{r}-1.185 \\
(0.264)\end{array}$ & $\begin{array}{l}-0.270 \\
(0.244)\end{array}$ \\
\hline $\begin{array}{l}\text { Log agg } \\
\text { demand }\end{array}$ & $\begin{array}{c}0.609 \\
(0.100)\end{array}$ & $\begin{array}{c}0.887 \\
(0.323)\end{array}$ & $\begin{array}{c}1.749 \\
(0.382)\end{array}$ & $\begin{array}{c}0.667 \\
(0.399)\end{array}$ \\
\hline \multirow[t]{2}{*}{ R squared } & 0.96 & 0.32 & & 0.28 \\
\hline & \multicolumn{4}{|c|}{ Panel B: Plastic (SIC 2821-2824) } \\
\hline $\begin{array}{l}\text { Log output } \\
\text { price }\end{array}$ & $\begin{array}{l}-0.260 \\
(0.114)\end{array}$ & $\begin{array}{l}-0.335 \\
(0.141)\end{array}$ & $\begin{array}{r}-0.945 \\
(0.474)\end{array}$ & $\begin{array}{l}-0.427 \\
(0.161)\end{array}$ \\
\hline $\begin{array}{l}\text { Log agg } \\
\text { demand }\end{array}$ & $\begin{array}{c}0.595 \\
(0.078)\end{array}$ & $\begin{array}{c}1.010 \\
(0.159)\end{array}$ & $\begin{array}{c}1.213 \\
(0.159)\end{array}$ & $\begin{array}{c}1.041 \\
(0.158)\end{array}$ \\
\hline \multirow[t]{2}{*}{ R squared } & 0.97 & 0.57 & 0.29 & 0.57 \\
\hline & \multicolumn{4}{|c|}{ Panel C: Petroleum (SIC 2911) } \\
\hline $\begin{array}{l}\text { Log output } \\
\text { price }\end{array}$ & $\begin{array}{c}0.121 \\
(0.040)\end{array}$ & $\begin{array}{l}-0.002 \\
(0.063)\end{array}$ & $\begin{array}{r}-0.050 \\
(0.121)\end{array}$ & $\begin{array}{l}-0.029 \\
(0.065)\end{array}$ \\
\hline $\begin{array}{l}\text { Log agg } \\
\text { demand }\end{array}$ & $\begin{array}{c}-0.473 \\
(0.152)\end{array}$ & $\begin{array}{c}0.424 \\
(0.287)\end{array}$ & $\begin{array}{c}0.538 \\
(0.335)\end{array}$ & $\begin{array}{c}0.488 \\
(0.267)\end{array}$ \\
\hline \multirow[t]{2}{*}{ R squared } & 0.80 & 0.06 & 0.03 & 0.05 \\
\hline & \multicolumn{4}{|c|}{ Panel D: Steel (SIC 3312) } \\
\hline $\begin{array}{l}\text { Log output } \\
\text { price }\end{array}$ & $\begin{array}{c}-1.012 \\
(0.272)\end{array}$ & $\begin{array}{l}-0.499 \\
(0.492)\end{array}$ & $\begin{array}{l}-4.455 \\
(3.746)\end{array}$ & $\begin{array}{l}-0.440 \\
(0.454)\end{array}$ \\
\hline $\begin{array}{l}\text { Log agg } \\
\text { demand }\end{array}$ & $\begin{array}{c}0.724 \\
(0.557)\end{array}$ & $\begin{array}{c}1.545 \\
(0.651)\end{array}$ & $\begin{array}{c}4.324 \\
(2.905)\end{array}$ & $\begin{array}{c}1.504 \\
(0.665)\end{array}$ \\
\hline R squared & 0.56 & 0.35 & & 0.32 \\
\hline
\end{tabular}

Notes: The table reports coefficient estimates with standard errors in parentheses, robust to heteroskedasticity. Each panel includes results for the indicated industry. Besides the reported coefficients, column 1 also includes a linear time trend. Columns 1 and 2 are estimated by Ordinary Least Squares. Columns 3 and 4 are estimated by two-stage least squares. The instrument in column 3 is the 4-digit TFP growth rate from the MPD. The instruments in column 4 include the log capital price, log average payroll per employee, log energy price, and log materials price for the corresponding industry. 
Table 3

\begin{tabular}{|c|c|c|c|c|}
\hline \multicolumn{5}{|c|}{ Elasticity Estimates for Industries 5-7 } \\
\hline \multirow{3}{*}{ Specification } & (1) & $(2)$ & (3) & (4) \\
\hline & Levels & First differences & $\begin{array}{c}\text { Instrument using } \\
\text { TFP, first } \\
\text { differences }\end{array}$ & $\begin{array}{l}\text { Instrument using } \\
\text { input prices, first } \\
\text { differences }\end{array}$ \\
\hline & \multicolumn{4}{|c|}{ Panel A: Portland cement (SIC 3241) } \\
\hline $\begin{array}{l}\text { Log output } \\
\text { price }\end{array}$ & $\begin{array}{c}-0.749 \\
(0.124)\end{array}$ & $\begin{array}{l}-0.684 \\
(0.147)\end{array}$ & $\begin{array}{l}-1.658 \\
(0.588)\end{array}$ & $\begin{array}{l}-0.737 \\
(0.193)\end{array}$ \\
\hline $\begin{array}{l}\text { Log agg } \\
\text { demand }\end{array}$ & $\begin{array}{c}0.850 \\
(0.264)\end{array}$ & $\begin{array}{c}0.825 \\
(0.137)\end{array}$ & $\begin{array}{c}1.049 \\
(0.239)\end{array}$ & $\begin{array}{c}0.837 \\
(0.144)\end{array}$ \\
\hline \multirow[t]{2}{*}{ R squared } & 0.53 & 0.57 & 0.10 & 0.57 \\
\hline & \multicolumn{4}{|c|}{ Panel B: Rolling and drawing (SIC 3351, 3356, 3357) } \\
\hline $\begin{array}{l}\text { Log output } \\
\text { price }\end{array}$ & $\begin{array}{c}-0.503 \\
(0.131)\end{array}$ & $\begin{array}{l}-0.313 \\
(0.177)\end{array}$ & $\begin{array}{l}-1.097 \\
(0.346)\end{array}$ & $\begin{array}{l}-0.192 \\
(0.203)\end{array}$ \\
\hline $\begin{array}{l}\text { Log agg } \\
\text { demand }\end{array}$ & $\begin{array}{c}0.263 \\
(0.172)\end{array}$ & $\begin{array}{c}0.867 \\
(0.273)\end{array}$ & $\begin{array}{c}1.377 \\
(0.368)\end{array}$ & $\begin{array}{c}0.788 \\
(0.294)\end{array}$ \\
\hline \multirow[t]{2}{*}{ R squared } & 0.45 & 0.29 & & 0.28 \\
\hline & \multicolumn{4}{|c|}{ Panel C: Pipe fitting (SIC 3429, 3432, 3491, 3492, 3494, 3499, 3728) } \\
\hline $\begin{array}{l}\text { Log output } \\
\text { price }\end{array}$ & $\begin{array}{r}-0.403 \\
(0.146)\end{array}$ & $\begin{array}{l}-0.565 \\
(0.128)\end{array}$ & $\begin{array}{l}-1.209 \\
(0.439)\end{array}$ & $\begin{array}{l}-0.572 \\
(0.184)\end{array}$ \\
\hline $\begin{array}{l}\text { Log agg } \\
\text { demand }\end{array}$ & $\begin{array}{c}0.706 \\
(0.115)\end{array}$ & $\begin{array}{c}0.700 \\
(0.204)\end{array}$ & $\begin{array}{c}0.970 \\
(0.224)\end{array}$ & $\begin{array}{c}0.703 \\
(0.233)\end{array}$ \\
\hline R squared & 0.92 & 0.36 & 0.11 & 0.36 \\
\hline
\end{tabular}

Notes: The table reports analogous specifications to Table 2 for the industries indicated in the panel titles. 
Table 4

\begin{tabular}{|c|c|c|c|c|}
\hline \multicolumn{5}{|c|}{ Elasticity Estimates for Industries 8-10 } \\
\hline & $(1)$ & $(2)$ & (3) & (4) \\
\hline Specification & Levels & First differences & $\begin{array}{c}\text { Instrument using } \\
\text { TFP, first } \\
\text { differences }\end{array}$ & $\begin{array}{l}\text { Instrument using } \\
\text { input prices, first } \\
\text { differences }\end{array}$ \\
\hline & \multicolumn{4}{|c|}{ Panel A: Misc. wood (SIC 2421, 2426, 2429, 2431, 2441, 2448, 2449, 2451, 2452, 2499, 3131) } \\
\hline $\begin{array}{l}\text { Log output } \\
\text { price }\end{array}$ & $\begin{array}{l}-0.465 \\
(0.152)\end{array}$ & $\begin{array}{l}-0.100 \\
(0.107)\end{array}$ & $\begin{array}{l}-2.025 \\
(1.295)\end{array}$ & $\begin{array}{l}-0.057 \\
(0.100)\end{array}$ \\
\hline $\begin{array}{l}\text { Log agg } \\
\text { demand }\end{array}$ & $\begin{array}{c}0.356 \\
(0.181)\end{array}$ & $\begin{array}{c}0.823 \\
(0.149)\end{array}$ & $\begin{array}{c}1.793 \\
(0.939)\end{array}$ & $\begin{array}{c}0.801 \\
(0.156)\end{array}$ \\
\hline R squared & 0.81 & 0.36 & & 0.35 \\
\hline \multicolumn{5}{|c|}{ Panel B: Pharmaceuticals (SIC 2833, 2834, 2835, 2836) } \\
\hline $\begin{array}{l}\text { Log output } \\
\text { price }\end{array}$ & $\begin{array}{l}-0.172 \\
(0.158)\end{array}$ & $\begin{array}{l}-0.585 \\
(0.153)\end{array}$ & $\begin{array}{l}-2.657 \\
(1.473)\end{array}$ & $\begin{array}{l}-0.646 \\
(0.310)\end{array}$ \\
\hline $\begin{array}{l}\text { Log agg } \\
\text { demand }\end{array}$ & $\begin{array}{c}0.097 \\
(0.113)\end{array}$ & $\begin{array}{c}0.290 \\
(0.225)\end{array}$ & $\begin{array}{c}1.687 \\
(1.083)\end{array}$ & $\begin{array}{c}0.332 \\
(0.307)\end{array}$ \\
\hline R squared & 1.00 & 0.24 & & 0.24 \\
\hline \multicolumn{5}{|c|}{ Panel C: Other electrical (SIC 3357, 3624, 3629, 3643, 3644, 3691, 3692, 3699) } \\
\hline $\begin{array}{l}\text { Log output } \\
\text { price }\end{array}$ & $\begin{array}{l}-0.297 \\
(0.196)\end{array}$ & $\begin{array}{l}-0.255 \\
(0.146)\end{array}$ & $\begin{array}{l}-4.132 \\
(3.337)\end{array}$ & $\begin{array}{l}-0.335 \\
(0.168)\end{array}$ \\
\hline $\begin{array}{l}\text { Log agg } \\
\text { demand }\end{array}$ & $\begin{array}{c}0.472 \\
(0.184)\end{array}$ & $\begin{array}{c}1.036 \\
(0.334)\end{array}$ & $\begin{array}{c}2.512 \\
(1.371)\end{array}$ & $\begin{array}{c}1.066 \\
(0.362)\end{array}$ \\
\hline R squared & 0.86 & 0.29 & & 0.28 \\
\hline
\end{tabular}

Notes: The table reports analogous specifications to Table 2 for the industries indicated in the panel titles. 
Table 5

Change in Full-Time Jobs per Industry-Wide One Million Dollar ${ }^{\mathrm{a}}$ Increase in Environmental Expenditure: MPS Industries and MPS Years ${ }^{b}$

\begin{tabular}{|c|c|c|c|c|c|c|c|}
\hline Industry & $\begin{array}{c}\text { Sample } \\
\text { Size }\end{array}$ & $\begin{array}{c}\text { Total } \\
\text { Effect } \\
\text { (reduced } \\
\text { form) }^{c}\end{array}$ & $\begin{array}{l}\text { Total } \\
\text { Effect }\end{array}$ & $\begin{array}{c}\text { Cost } \\
\text { Effect }\end{array}$ & $\begin{array}{c}\text { Factor } \\
\text { Shift }\end{array}$ & $\begin{array}{c}\text { Demand } \\
\text { Effect }\end{array}$ & $\begin{array}{l}\text { Demand } \\
\text { Elasticity }^{\mathrm{d}}\end{array}$ \\
\hline (1) & $(2)$ & (3) & (4) & (5) & (6) & (7) & (8) \\
\hline \multicolumn{8}{|c|}{ Panel A: MPS Estimates ${ }^{\mathrm{e}}$ (standard errors in parentheses) } \\
\hline 1 Paper & 615 & -- & $\begin{array}{l}-0.89 \\
(2.15)\end{array}$ & $\begin{array}{c}1.73 \\
(1.25)\end{array}$ & $\begin{array}{l}-0.29 \\
(1.63)\end{array}$ & $\begin{array}{l}-2.33 \\
(1.99)\end{array}$ & $\begin{array}{c}1.34 \\
(0.17)\end{array}$ \\
\hline 2 Petroleum & 717 & -- & $\begin{array}{c}1.65 \\
(0.67)\end{array}$ & $\begin{array}{c}0.49 \\
(0.18)\end{array}$ & $\begin{array}{c}1.35 \\
(0.62)\end{array}$ & $\begin{array}{c}-0.2 \\
(0.17)\end{array}$ & $\begin{array}{c}0.40 \\
(0.19)\end{array}$ \\
\hline 3 Plastics & 404 & -- & $\begin{array}{c}4.61 \\
(2.14)\end{array}$ & $\begin{array}{c}2.16 \\
(1.09)\end{array}$ & $\begin{array}{c}3.51 \\
(1.64)\end{array}$ & $\begin{array}{l}-1.06 \\
(1.16)\end{array}$ & $\begin{array}{c}0.49 \\
(0.29)\end{array}$ \\
\hline 4 Steel & 536 & -- & $\begin{array}{c}0.30 \\
(4.38)\end{array}$ & $\begin{array}{c}3.14 \\
(1.58)\end{array}$ & $\begin{array}{c}3.01 \\
(2.51)\end{array}$ & $\begin{array}{l}-5.85 \\
(4.04)\end{array}$ & $\begin{array}{c}1.86 \\
(0.35)\end{array}$ \\
\hline \multicolumn{8}{|c|}{ Panel B: Current Estimates (standard errors in parentheses) } \\
\hline 1 Paper & 824 & $\begin{array}{c}1.58 \\
(1.82)\end{array}$ & $\begin{array}{l}6.43^{*} \\
(2.02)\end{array}$ & $\begin{array}{l}6.12^{*} \\
(1.35)\end{array}$ & $\begin{array}{c}2.72 \\
(1.62)\end{array}$ & $\begin{array}{l}-2.41 \\
(1.53)\end{array}$ & $\begin{array}{c}0.27 \\
(0.24)\end{array}$ \\
\hline 2 Petroleum & 697 & $\begin{array}{c}0.43 \\
(0.89)\end{array}$ & $\begin{array}{c}1.11 \\
(0.91)\end{array}$ & $\begin{array}{c}0.77 \\
(0.29)\end{array}$ & $\begin{array}{c}0.37 \\
(0.96)\end{array}$ & $\begin{array}{l}-0.03 \\
(0.05)\end{array}$ & $\begin{array}{c}0.03 \\
(0.07)\end{array}$ \\
\hline 3 Plastics & 548 & $\begin{array}{l}10.39 \\
(5.06)\end{array}$ & $\begin{array}{c}19.99 * \\
(4.3)\end{array}$ & $\begin{array}{l}15.48^{*} \\
(2.89)\end{array}$ & $\begin{array}{l}12.26 * \\
(3.36)\end{array}$ & $\begin{array}{l}-7.75 \\
(2.8)\end{array}$ & $\begin{array}{c}0.43 \\
(0.16)\end{array}$ \\
\hline 4 Steel & 486 & $\begin{array}{l}38.57^{*} \\
(11.96)\end{array}$ & $\begin{array}{l}14.99 \\
(9.82)\end{array}$ & $\begin{array}{c}16.21 * \\
(3.65)\end{array}$ & $\begin{array}{c}7.58 \\
(7.18)\end{array}$ & $\begin{array}{l}-8.80 \\
(7.68)\end{array}$ & $\begin{array}{c}0.44 \\
(0.45)\end{array}$ \\
\hline
\end{tabular}

Notes: (a) The $\$ 1 \mathrm{M}$ increase is in 1997\$. (b) The years included are 1979, 1980, 1981, 1985, 1988, and 1991. (c) The dependent variable in the reduced-form model is the log of plant-level employment, and the independent variables include the plant-level ratio of PAOC to production costs, the logs of prices (energy, labor, capital) normalized with respect to price of materials, log capital stock, year fixed effects, and plant fixed effects. The equation is estimated by OLS, and heterogeneity-robust standard errors are reported. (d) MPS demand elasticities are from MPS Table II, p. 425; Current demand elasticities are negatives of "Log output price" coefficient from Table 2, column (4) of this document. Standard errors are reported in parentheses. (e) MPS estimates are derived from MPS Table III, p. 427. The original estimates were expressed per \$1M increase in $1987 \$$. For consistency with the rest of the results, the original MPS estimates were adjusted to represent changes in employment per $\$ 1 \mathrm{M}$ increase in 1997\$, using industry-specific deflators. $\left({ }^{*}\right)$ Denotes a statistically significant estimate at $5 \%$ joint significance level. The Type I error was controlled using the Holm-Bonferroni procedure (Holm, 1979). The family of tests included all tests of employment effect significance in this table (36 tests) and in Table 6 (50 tests) to enable joint conclusions (Bender and Lange, 2001). 
Table 6

Change in Full-Time Jobs per Industry-Wide One Million Dollar ${ }^{\mathrm{a}}$ Increase in Environmental Expenditure: All Industries and All Years ${ }^{b}$

\begin{tabular}{|c|c|c|c|c|c|c|c|}
\hline Industry & $\begin{array}{c}\text { Sample } \\
\text { Size }\end{array}$ & $\begin{array}{c}\text { Total } \\
\text { Effect } \\
\text { (reduced }^{\text {redurm) }} \\
\text { form }^{c}\end{array}$ & $\begin{array}{l}\text { Total } \\
\text { Effect }\end{array}$ & $\begin{array}{c}\text { Cost } \\
\text { Effect }\end{array}$ & $\begin{array}{c}\text { Factor } \\
\text { Shift }\end{array}$ & $\begin{array}{c}\text { Demand } \\
\text { Effect }\end{array}$ & $\begin{array}{l}\text { Demand } \\
\text { Elasticity }^{\mathrm{d}}\end{array}$ \\
\hline (1) & (2) & (3) & (4) & (5) & (6) & (7) & (8) \\
\hline \multicolumn{8}{|c|}{ Panel A: MPS Industries (standard errors in parentheses) } \\
\hline 1 Paper & 2928 & $\begin{array}{l}0.78^{*} \\
(0.19)\end{array}$ & $\begin{array}{l}2.68^{*} \\
(0.64)\end{array}$ & $\begin{array}{l}0.91 \\
(0.4)\end{array}$ & $\begin{array}{c}2.02 \\
(0.65)\end{array}$ & $\begin{array}{l}-0.25 \\
(0.27)\end{array}$ & $\begin{array}{c}0.27 \\
(0.24)\end{array}$ \\
\hline 2 Petroleum & 2263 & $\begin{array}{c}0.61 \\
(0.36)\end{array}$ & $\begin{array}{l}2.66^{*} \\
(0.42)\end{array}$ & $\begin{array}{l}1.38 * \\
(0.16)\end{array}$ & $\begin{array}{c}1.31 \\
(0.43)\end{array}$ & $\begin{array}{l}-0.04 \\
(0.09)\end{array}$ & $\begin{array}{c}0.03 \\
(0.07)\end{array}$ \\
\hline 3 Plastics & 2515 & $\begin{array}{c}1.08 \\
(1.38)\end{array}$ & $\begin{array}{c}31.21 * \\
(5.19)\end{array}$ & $\begin{array}{l}7.36 * \\
(0.97)\end{array}$ & $\begin{array}{c}27.01^{*} \\
(5.05)\end{array}$ & $\begin{array}{l}-3.17 \\
(1.25)\end{array}$ & $\begin{array}{c}0.43 \\
(0.16)\end{array}$ \\
\hline 4 Steel & 1639 & $\begin{array}{c}28.55^{*} \\
(5.29)\end{array}$ & $\begin{array}{c}21.69 \\
(7.2)\end{array}$ & $\begin{array}{c}14.45^{*} \\
(1.78)\end{array}$ & $\begin{array}{c}13.59 * \\
(3.25)\end{array}$ & $\begin{array}{r}-6.36 \\
(6.6)\end{array}$ & $\begin{array}{c}0.44 \\
(0.45)\end{array}$ \\
\hline \multicolumn{8}{|c|}{ Panel B: Additional Industries (standard errors in parentheses) } \\
\hline 5. Portland Cement & 1032 & $\begin{array}{l}2.29 \\
(1.6)\end{array}$ & $\begin{array}{c}3.48 \\
(1.73)\end{array}$ & $\begin{array}{l}5.17^{*} \\
(1.26)\end{array}$ & $\begin{array}{c}2.14 \\
(1.53)\end{array}$ & $\begin{array}{l}-3.82 \\
(1.38)\end{array}$ & $\begin{array}{c}0.74 \\
(0.19)\end{array}$ \\
\hline $\begin{array}{l}\text { 6. Rolling and } \\
\text { Drawing }\end{array}$ & 1388 & $\begin{array}{l}-3.88 \\
(9.41)\end{array}$ & $\begin{array}{l}22.68^{*} \\
(6.57)\end{array}$ & $\begin{array}{l}16.07^{*} \\
(3.72)\end{array}$ & $\begin{array}{c}9.66 \\
(5.98)\end{array}$ & $\begin{array}{l}-3.05 \\
(3.35)\end{array}$ & $\begin{array}{c}0.19 \\
(0.20)\end{array}$ \\
\hline 7. Pipe Fitting & 868 & $\begin{array}{l}-54.35 \\
(25.11)\end{array}$ & $\begin{array}{c}16.14 \\
(21.55)\end{array}$ & $\begin{array}{c}50.65 \\
(21.63)\end{array}$ & $\begin{array}{c}-5.65 \\
(18.78)\end{array}$ & $\begin{array}{l}-28.87 \\
(16.25)\end{array}$ & $\begin{array}{c}0.57 \\
(0.18)\end{array}$ \\
\hline $\begin{array}{l}\text { 8. Misc. Wood } \\
\text { Products }\end{array}$ & 922 & $\begin{array}{l}-66.85 \\
(35.68)\end{array}$ & $\begin{array}{c}13.66 \\
(19.02)\end{array}$ & $\begin{array}{c}25.32 \\
(12.25)\end{array}$ & $\begin{array}{c}-0.52 \\
(14.88)\end{array}$ & $\begin{array}{l}-11.14 \\
(13.26)\end{array}$ & $\begin{array}{c}0.44 \\
(0.45)\end{array}$ \\
\hline 9. Pharmaceuticals & 1579 & $\begin{array}{c}0.14 \\
(1.69)\end{array}$ & $\begin{array}{l}-1.66 \\
(3.29)\end{array}$ & $\begin{array}{c}4.48 \\
(1.73)\end{array}$ & $\begin{array}{l}-3.23 \\
(3.11)\end{array}$ & $\begin{array}{l}-2.91 \\
(1.86)\end{array}$ & $\begin{array}{c}0.65 \\
(0.31)\end{array}$ \\
\hline $\begin{array}{l}\text { 10. Other Electrical } \\
\text { Equipment }\end{array}$ & 1805 & $\begin{array}{l}-11.32 \\
(5.21)\end{array}$ & $\begin{array}{l}10.17 \\
(6.52)\end{array}$ & $\begin{array}{l}-4.28 \\
(4.67)\end{array}$ & $\begin{array}{l}12.99 \\
(6.68)\end{array}$ & $\begin{array}{c}1.45 \\
(1.90)\end{array}$ & $\begin{array}{c}0.34 \\
(0.17)\end{array}$ \\
\hline
\end{tabular}

Notes: (a) The \$1M increase is in 1997\$. (b) The years included are: 1976-1982, 1984-1986, 1988-1994, 1999, and 2005. (c) The dependent variable in the reduced-form model is the log of plant-level employment and the independent variables include the plant-level ratio of PAOC to production costs, the logs of prices (energy, labor, capital) normalized with respect to price of materials, log capital stock, year fixed effects and plant fixed effects. The equation is estimated by OLS and heterogeneityrobust standard errors are reported. (d) Demand elasticities are negatives of "Log output price" coefficient from Tables 3 and 4, column (4) of this document. Standard errors are reported in parentheses. (*) Denotes a statistically significant estimate at $5 \%$ joint significance level. The Type I error was controlled using the Holm-Bonferroni procedure (Holm, 1979). The family of tests included all tests of employment effect significance in Table 5 (36 tests) and in this table ( 50 tests) to enable joint conclusions (Bender and Lange, 2001). 
Table 7

Characteristics of the Current Sample for MPS Industries and Years vs. MPS Sample ${ }^{a}$

\begin{tabular}{|c|c|c|c|c|c|c|}
\hline \multirow{2}{*}{$\begin{array}{l}\text { Characteristic: } \\
\text { Analysis: }\end{array}$} & \multicolumn{2}{|c|}{ Sample Size } & \multicolumn{2}{|c|}{$\begin{array}{c}\text { Labor as a Share of } \\
\text { Total Costs }\end{array}$} & \multicolumn{2}{|c|}{$\begin{array}{c}\text { PAOC as a Share of } \\
\text { Total Costs }\end{array}$} \\
\hline & MPS & Current & MPS & Current & MPS & Current \\
\hline 1 Paper $^{b}$ & 615 & 824 & 0.201 & 0.117 & 0.028 & 0.017 \\
\hline 2 Petroleum & 717 & 697 & 0.019 & 0.016 & 0.011 & 0.009 \\
\hline 3 Plastics & 404 & 548 & 0.085 & 0.082 & 0.020 & 0.011 \\
\hline 4 Steel $^{c}$ & 536 & 486 & 0.230 & 0.173 & 0.022 & 0.012 \\
\hline
\end{tabular}

Notes: (a) MPS sample statistics is are from MPS Table I, p. 422. (b) Paper industry definition in MPS excluded pulp mills. (c) Steel industry definition in MPS included coke ovens. 
Table 8

Estimated Total Factor Productivity ${ }^{a}$ by Industry for All Available Years ${ }^{b}$

\begin{tabular}{|c|c|c|c|c|c|c|c|c|c|c|c|}
\hline \multirow[b]{2}{*}{ Industry } & \multicolumn{3}{|c|}{ Standard Deviation } & \multirow{2}{*}{$\begin{array}{l}\text { Mean } \\
\text { = } \\
\frac{\pi}{0}\end{array}$} & \multicolumn{7}{|c|}{ Mean by time period } \\
\hline & $\begin{array}{l}\overline{\bar{\pi}} \\
\overline{0} \\
0\end{array}$ & 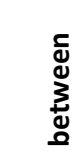 & $\frac{5}{\frac{5}{5}}$ & & 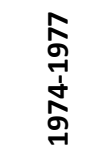 & 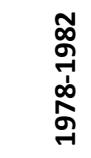 & 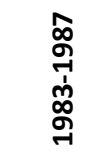 & 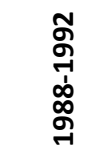 & $\begin{array}{l}\text { જ̆ } \\
\text { જ̆ } \\
\text { ભ̆ } \\
\text { જે }\end{array}$ & 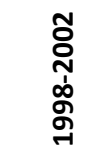 & 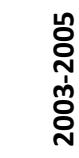 \\
\hline 1 Paper & 0.29 & 0.24 & 0.19 & 2.17 & 2.19 & 2.19 & 2.17 & 2.15 & 2.14 & 2.15 & 2.14 \\
\hline 2 Petroleum & 0.42 & 0.44 & 0.31 & 1.42 & 1.43 & 1.42 & 1.46 & 1.42 & 1.37 & 1.38 & 1.35 \\
\hline 3 Plastics & 0.49 & 0.44 & 0.28 & 0.83 & 0.97 & 0.90 & 0.83 & 0.82 & 0.72 & 0.71 & 0.64 \\
\hline 4 Steel & 0.29 & 0.21 & 0.22 & 2.40 & 2.40 & 2.40 & 2.39 & 2.40 & 2.39 & 2.39 & 2.39 \\
\hline 5 Portland cement & 0.31 & 0.24 & 0.22 & 4.49 & 4.45 & 4.47 & 4.49 & 4.51 & 4.51 & 4.52 & 4.52 \\
\hline 6 Rolling and drawing & 0.31 & 0.23 & 0.22 & 1.49 & 1.50 & 1.50 & 1.49 & 1.48 & 1.47 & 1.46 & 1.44 \\
\hline 7 Pipe fitting & 0.68 & 0.52 & 0.32 & 2.74 & 2.79 & 2.79 & 2.74 & 2.70 & 2.66 & 2.60 & 2.41 \\
\hline 8 Misc. Wood Products & 0.32 & 0.26 & 0.19 & 0.65 & 0.76 & 0.72 & 0.68 & 0.61 & 0.59 & 0.49 & 0.50 \\
\hline 9 Pharmaceuticals & 0.98 & 0.87 & 0.52 & -1.98 & -1.79 & -1.84 & -1.90 & -2.04 & -2.26 & -2.40 & -2.36 \\
\hline $\begin{array}{l}10 \text { Other electrical } \\
\text { equipment }\end{array}$ & 0.44 & 0.34 & 0.30 & 3.48 & 3.47 & 3.48 & 3.47 & 3.49 & 3.50 & 3.50 & 3.39 \\
\hline
\end{tabular}

Notes: (a) Plant-specific TFPs were computed based on the production function estimates obtained from the Olley-Pakes model. The summary statistics reported are natural logs of TFP. (b) The years included are: 1976-1982, 1984-1986, 1988-1994 1999, and 2005. 
Figure 1

Sources of Difference between Current and MPS Estimates of Employment Effects (MPS years)

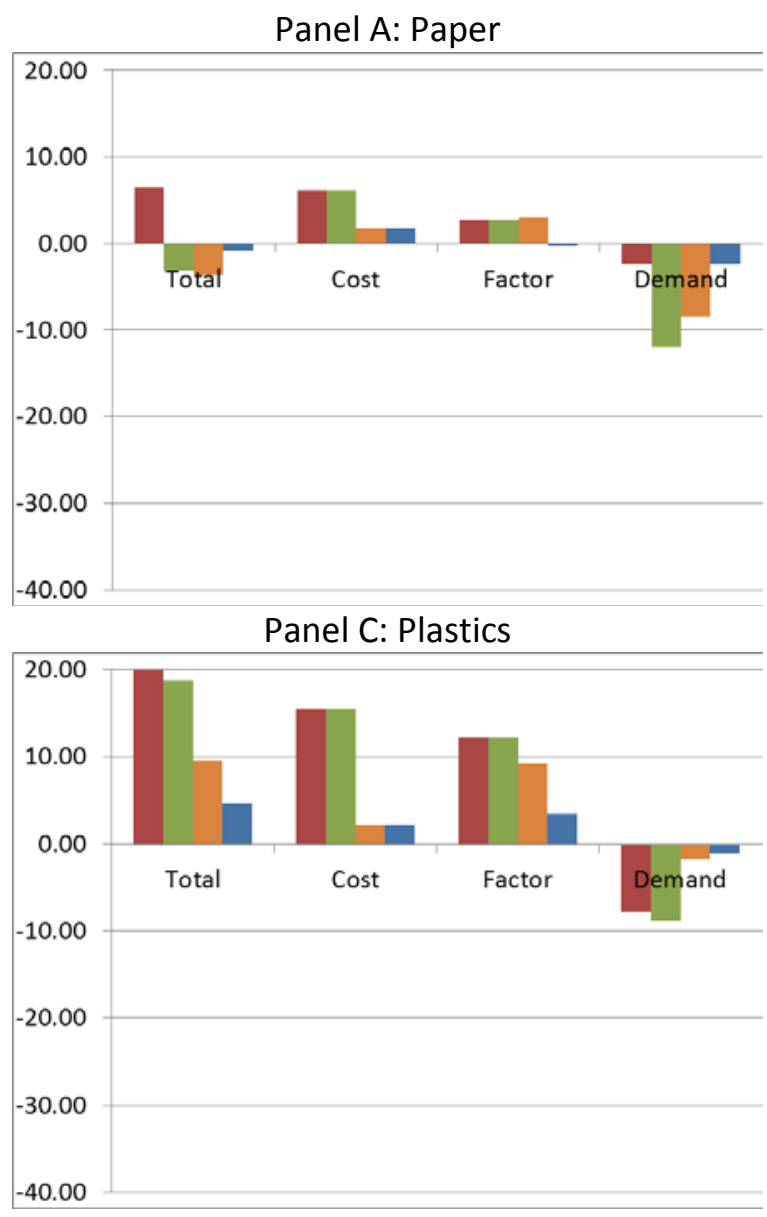

- 1. Current estimate

a. Estimate based on MPS cost function and MPS demand elasticity
Panel B: Petroleum

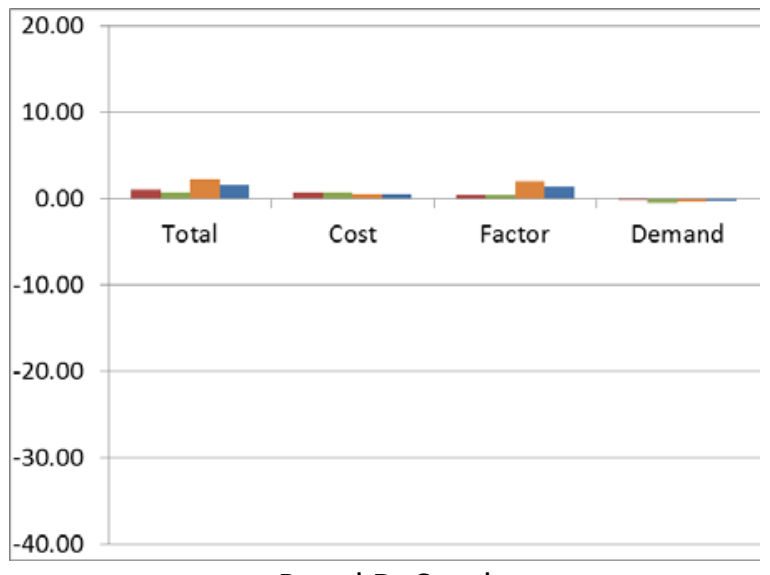

Panel D: Steel

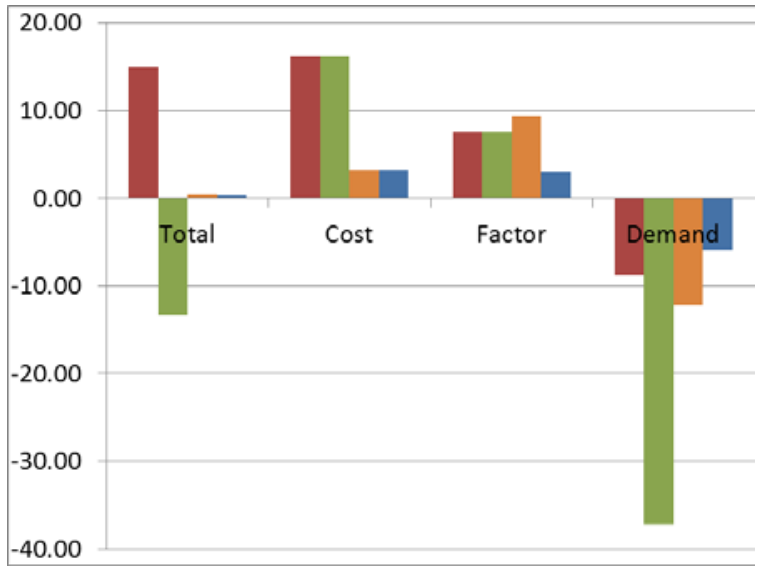

2. Estimate based on current cost function and MPS demand elasticity 4. MPS estimate

Notes:

- The difference between (1) and (2) is that the MPS demand elasticity was used in combination with the current cost function estimate to derive the demand effect and the total effect. (There is no change in the cost effect and the factor effect.)

- The difference between (2) and (3) is that, in addition to MPS demand elasticities, MPS cost function estimates were used to decompose the employment impacts.

- The difference between (3) and (4) is that the current sample averages were used for the decomposition for (3), while (4) is the published MPS estimate, using the MPS data. 